\title{
CONTRABANDO LEGISLATIVO E A IMPLANTAÇÃO DO ESTALEIRO ENSEADA INDÚSTRIA NAVAL: CAMINHOS E DESCAMINHOS DO EMPREENDIMENTO
}

\section{CONTRABATING LEGISLATIVE AND THE IMPLEMENTATION OF THE YEAR ENSECTED NAVAL INDUSTRY: PATHWAYS AND DEADLINES OF THE ENTERPRISE}

\author{
Ícaro Argolo Ferreira ${ }^{1}$
}

\section{RESUMO}

O artigo trata dos caminhos e descaminhos na implantação do Estaleiro Enseada Indústria Naval, empreendimento que envolveu alterações normativas de impacto na área escolhida. Para tanto, toma-se por base o ano de 2009, onde foram elaborados estudos e documentos, como o Estudo de Impacto Ambiental (EIA) e o Relatório de Impacto Ambiental (RIMA), resoluções e pareceres técnicos sobre os possíveis impactos resultantes do processo de implantação, ao meio ambiente, à economia e às famílias que viviam na Reserva Baía do Iguape, em Maragojipe ${ }^{2}$. No processo de discussão e estudo para a liberação das obras, e diante dos obstáculos legais apontadas desde a apresentação do projeto, foram realizados alguns mecanismos de acomodação, negociação e ajustes, especialmente de aspectos conflitivos, que dizem respeito tanto ao ambiente físico e seus limites jurídicos, como as condições de bem-estar e direitos das populações locais. Como objetivo o artigo busca analisar o processo e as assimetrias inerentes aos usos do território pela implantação do empreendimento. A metodologia do estudo consiste na análise documental, situacional da área do empreendimento e entrevistas com membros da comunidade envolvida.

Palavras-chave: Estaleiro Enseada Indústria Naval, Estudo de Impacto Ambiental, Maragojipe, Contrabando Legislativo.

\footnotetext{
${ }^{1}$ Doutor em Políticas Sociais e Cidadania (UCSal), Professor de Direito na FACEMP. Contato principal para correspondência. Universidade Católica do Salvador - UCSAL, Bahia - Brasil. ORCID Id: http://orcid.org/00000001-7921-4463 Lattes: http://lattes.cnpq.br/8637270011810 http://lattes.cnpq.br/1498834795084888 347 E-mail: adv.icaroargolo@gmail.com

${ }^{2} \mathrm{~A}$ opção por escrever o nome de Maragojipe com "j" e não com "g", se dá objetivamente em função da eficácia do Formulário Ortográfico de 1943, que embora disponha em seu parágrafo 33 que as palavras deverão ser escritas respeitando-se sua etimologia e sua história; bem como, em seu parágrafo 39 estende esse entendimento aos nomes próprios; estabelece no parágrafo 42 que há uma exceção às cidades com tradições históricas a mais de um século. Portanto, embora a cidade tenha uma longa história, ela não tem sua grafia histórica consagrada pelo consenso, como diz o acordo: "consagrada pelo consenso diuturno dos brasileiros", assim a etimologia do nome prevalece nesse caso a mandar grafar com "j" as palavras de origem indígena, como é Maragojipe. (Disponível em: http://linguaportuguesabyrogeriomarques.blogspot.com /2009/08/resposta-maragojipe-pode-ser-escrito.html. Acesso em: 27 set. 2017).
} 


\section{SUMMARY}

The article deals with the paths and paths in the implementation of Enseada Indústria Naval Shipyard, a venture that involved normative changes of impact in the chosen area. To this end, it is based on 2009, where studies and documents were prepared, such as the Environmental Impact Study (EIA) and the Environmental Impact Report (RIMA), resolutions and technical opinions on the possible impacts resulting from the process. the environment, the economy and the families living in the Baía do Iguape Reserve in Maragojipe. In the process of discussion and study for the release of the works, and in view of the legal obstacles pointed out since the presentation of the project, some mechanisms of accommodation, negotiation and adjustments were made, especially of conflicting aspects, which concern both the physical environment and its limits. such as welfare conditions and rights of local populations. The objective of this paper is to analyze the process and the asymmetries inherent to the territory uses for the implementation of the enterprise. The methodology of the study consists in the documentary, situational analysis of the enterprise area and interviews with members of the community involved.

Keywords: Shipyard Cove Shipyard, Environmental Impact Study, Maragojipe, Legislative Smuggling.

\section{INTRODUÇÃO}

O processo de desenvolvimento e crescimento econômicos afeta de forma nem sempre conciliável a relação entre sociedade e natureza e envolve um quadro de conflito e disputa entre projetos e agentes sociais, e formas de agenciamento e arranjos entre atores distintos, sobre o território.

A implementação de empreendimentos, como o Estaleiro Enseada Indústria Naval, no âmbito dos territórios confronta com um ordenamento sociocultural e legal preexistente, afetando, portanto, saberes, formas de organização e reprodução dos moradores locais e as comunidades que viviam das atividades extrativistas tradicionais.

Nesse sentido, a regulação produtiva proposta pelo Estado, na forma de uma intervenção racional e programada de projetos de grande impacto sobre frações do território nacional expressa um quadro de conflitos entre projetos, sentidos e fins que implicam arranjos e redefinição entre agentes no curso de um processo de implantação de projetos no âmbito do local. Esses processos 
envolvem disputa pelo controle do acesso e o uso destes recursos, a partir de distintos modos de inter-relacionamento ecológico.

Pode-se inferir, portanto, que a implementação de projetos governamentais não se constitui exclusivamente numa proposição técnica de implementação de programas econômicos produtivos e de crescimento, mas se constituem também em processos políticos, que implicam a articulação de interesses entre diversas escalas das instâncias decisórias públicas), entre setores do Executivo e da justiça e agentes públicos e sociedade, ou seja, os agentes econômicos de distinta grandeza (a exemplo das empresas do Consórcio responsável pela construção do empreendimento - Estaleiro), os pequenos empreendedores locais e as comunidades territoriais vinculadas às economias tradicionais, a exemplo de pescadores, quilombolas etc.

A reestruturação do território para novos usos é acompanhada por regulações institucionais, cuja evolução expressa diferentes contextos que hierarquizam, inclusive institucionalmente, o sentido de uso e exploração de bens e recursos pré-existentes desse território, em relação à preservação ambiental e ao reconhecimento de direitos de grupos e comunidades pré-existentes em favor da implantação de um estaleiro como parte da recriação de um polo naval no Brasil.

Objetiva-se analisar com este estudo como se deu o processo e suas assimetrias inerentes aos usos do território para a implantação do Estaleiro. Como se pretende mostrar esta realidade a partir da análise do Estudo de Impacto Ambiental e do Relatório de Impacto Ambiental, bem como de documentos institucionais originários do Instituto Brasileiro do Meio Ambiente e dos Recursos Naturais Renováveis; Ministério Público Federal; do Banco Nacional de Desenvolvimento Econômico e Social e entrevistas serão apresentados resultados de uma reflexão realizada vinculada aos achados documentais e da vivência transmitida por atores locais através das entrevistas.

\section{O PROCESSO DE ACOMODAÇÃO LEGAL DO TERRITÓRIO}

Dentre as dificuldades apresentadas no estudo de impacto ambiental, o conflito regulatório entre o empreendimento e a área recém regulada ${ }^{3}$ da Reserva Extrativista Marinha da Baía do

\footnotetext{
${ }^{3}$ Segundo Ferreira (2017) desde o início dos estudos para implantação do empreendimento observa-se o conflito legal, uma vez que a área escolhida para o empreendimento confrontava com os limites territoriais da RESEX Baía do Iguape (Lei Federal no 12.058/2009).
} 
Iguape (RESEX), assumiu importância maior, pois confrontava limites legais de parte da área territorial da Reserva Extrativista da Marinha Baía do Iguape, definida desde 2000 (Decreto presidencial ${ }^{4}$, de 11 de agosto de 2000). Essa regulação da proteção ambiental impedia que a área fosse destinada para outros fins que não fossem o direito assegurado ao desenvolvimento das atividades extrativistas. Para solucionar esse conflito legal o governo do Estado comprometeu-se com o IBAMA, em abril de 2009, a realizar uma revisão da área da RESEX de forma a permitir a instalação do empreendimento.

18/03/2009: O IBAMA, reiterou à presidência do ICMBio, os termos do Oficio anterior; 23/04/2009: a Secretaria de Indústria, Comércio e Mineração do Estado da Bahia encaminhou, ao IBAMA, o Oficio no 08/2009, no qual informa que o Estado da Bahia "realizará os atos necessários para revisar as poligonais nas áreas em que se postula a instalação dos empreendimentos da Indústria Naval". Isto ocorre em função da sobreposição com a área da RESEX Baía do Iguape. (PARECER TÉCNICO № 042/2010-COTRA/CGTMO/DILIC/IBAMA, p. $\left.3^{5}\right)$.

A alteração se deu exatamente em 13 de outubro de 2009, por meio da Lei no 12.058/2009 (art. 28) que promoveu a conversão em lei da Medida Provisória no 462/2009, de 14 de maio de 2009. Editada em 14 de maio de 2009, a MP dispunha previamente sobre a prestação de apoio financeiro pela União aos entes federados que recebem recursos do Fundo de Participação dos Municípios - FPM, no exercício de 2009, com o objetivo de superar dificuldades financeiras emergenciais.

A MP 462/2009, ao final, foi convertida na Lei 12.058/09 disciplinando, além do assunto original, uma farta gama de temas completamente diversos ao original, conforme se extrai da ementa transcrita:

[...] dispõe sobre a prestação de apoio financeiro pela União aos entes federados que recebem recursos do Fundo de Participação dos Municípios FPM, no exercício de 2009, com o objetivo de superar dificuldades financeiras emergenciais; altera as Leis nos 11.786 , de 25 de setembro de 2008, 9.503, de 23 de setembro de 1997, 11.882, de 23 de dezembro de 2008, 10.836, de 9 de janeiro de 2004, 11.314, de 3 de julho de 2006, 11.941, de 27 de maio de 2009, 10.925, de 23 de julho de 2004, 9.636, de 15 de maio de 1998, 8.036, de 11 de maio de 1990, 8.212, de 24 de julho de 1991, 10.893, de 13 de julho de 2004, 9.454, de 7 de abril de 1997, 11.945, de 4 de junho de 2009, 11.775,

${ }^{4}$ Cria a Reserva Extrativista Marinha da Baia do Iguapé, nos Municípios de Maragojipe e Cachoeira, Estado da Bahia, e dá outras providências. Disponível em: http://www.planalto.gov.br/ccivil_03/dnn/2000 /Dnn8999.htm. Acesso em: 02 fev. 2018

${ }^{5}$ Disponível em https://comissaoproiguape.files.wordpress.com/2010/05/parecer-tecnico.pdf. Acesso em: 10 mar. 2018 
de 17 de setembro de 2008, 11.326, de 24 de julho de 2006, 8.427, de 27 de maio de 1992, 8.171, de 17 de janeiro de 1991, 5.917, de 10 de setembro de 1973, 11.977, de 7 de julho de 2009, 11.196, de 21 de novembro de 2005, 9.703, de 17 de novembro de 1998, 10.865, de 30 de abril de 2004, 9.984, de 17 de julho de 2000, e 11.772, de 17 de setembro de 2008, a Medida Provisória no 2.197-43, de 24 de agosto de 2001, e o Decreto-Lei no 1.455, de 7 de abril de 1976; revoga a Lei no 5.969, de 11 de dezembro de 1973, e o art. 13 da Lei no 11.322, de 13 de julho de 2006; e dá outras providências. (BRASIL, 2009)

A MP 462 foi a última medida provisória com possibilidade de incluir as chamadas "emendas jabutis ou de contrabando", que acabavam por avolumar o processo legislativo de tal forma a travar as pautas e resultar na letargia daquele poder. O então presidente da Câmara dos Deputados, Michel Temer, em 17 de março de 2009, decretou novo entendimento ${ }^{7}$ ao $\S 6$ 으 do artigo 62 da Constituição da República Federativa do Brasil que, na prática deu fim às emendas sobre matérias diferentes do texto principal da medida provisória. A decisão provocou uma corrida de parlamentares interessados em incluir assuntos diversos no corpo da MP 462, entre elas a alteração da poligonal da Resex Baía de Iguape.

A MP no 462/2009 sofreu 23 emendas no Senado Federal, sendo incluídas no texto legal de conversão, matérias estranhas à original, entre elas a modificação dos limites territoriais da Reserva Extrativista Marinha Baía de Iguape. A alteração da poligonal da RESEX promoveu a retirada de algumas áreas e a inclusão de outras, o que resultou na ampliação final da RESEX em 2.211.73 hectares. Foram utilizados como argumentos para a alteração do território da Baía de Iguape a suposta existência de erro que fazia com que o estaleiro estivesse localizado parcialmente dentro da RESEX Baía de Iguape.

Essa redefinição de limites de área da reserva significou uma acomodação legal em favor do empreendimento, com a diminuição dos limites da regulação anterior de proteção ambiental. Assim, o Projeto de Lei no 5.892, de 13 de outubro de 2009, do Poder Executivo, alterou os limites originais da Reserva, situada nos municípios de Maragojipe e Cachoeira (estado da Bahia), estabelecendo fronteiras legais ao novo empreendimento. Esse projeto de Lei foi aprovado pela Assembleia Legislativa em sua constitucionalidade, juridicidade e boa técnica legislativa, com

\footnotetext{
${ }^{6}$ Termo utilizado para descrever emendas que não se referem ao conteúdo principal da medida provisória.

${ }^{7}$ Discurso proferido na Sessão: 037.3.53.0, em 17/03/2009. Disponível em: https://www.camara.leg.br/internet/sitaqweb/TextoHTML.asp?etapa=3\&nuSessao=037.3.53.0\&nuQuarto =74\&nuOrador=2\&nulnsercao=0\&dtHorarioQuarto=16:26\&sgFaseSessao=OD\%20\%20\%20\%20\%20\%20\%20 \%20\&Data=17/03/2009\&txApelido=PRESIDENTE\&txEtapa=Com\%20reda\%C3\%A7\%C3\%A30\%20final. Acesso em 20/09/2017. Acesso em: 29 set. 2018.
} 
parecer favorável do relator na Comissão de Constituição de Justiça e de Cidadania (CCJ), o então deputado Federal Colbert Martins (MDB).

O novo decreto, com o redimensionamento dos limites da poligonal da Reserva Extrativista Marinha da Baía do Iguape implicou um recuo da linha demarcatória da Reserva Extrativista nas proximidades do estaleiro de São Roque e permitiu uma regularização espacial favorável à indústria naval, impulsionando, assim, o empreendimento, mas afetando diretamente a dinâmica da economia e ordem social local pré-existentes.

Esse processo de acomodação legal, implementado pelos órgãos governamentais e aprovado pelo legislativo estadual, permitiu que a área escolhida para a implantação do empreendimento não confrontasse "legalmente" com os limites da Reserva, mas significou concretamente, uma reorientação dos destinos e usos da área, em favor do projeto nacional do polo naval, espoliando recursos e limites legais anteriores e produzindo uma "desterritorialização" (PROST, 2009 e 2010) dos grupos que extraiam dessa área o seu sustento.

Em 29 de setembro de 2009, o IBAMA encaminhou, através do Oficio no 253/2009, o Termo de Referência definitivo para elaboração do EIA/RIMA; em 23 de novembro de 2009, o empreendedor apresentou o EIA/RIMA do empreendimento para a equipe do IBAMA que após realização de check-list, elaborou a Nota Técnica no 161/2009-COTRA/CGTMO/DILIC/IBAMA, na qual demanda alterações/complementações de uma série de itens relacionados ao meio biótico, além da adequação do RIMA, considerado extenso e com linguagem excessivamente técnica.

Como parte da negociação e, em contrapartida à avaliação do IBAMA, o Consórcio responsável pelo Estaleiro Enseada do Paraguaçu ${ }^{8}$ protocolou junto ao IBAMA, em 30 de novembro de 2009, um parecer em que se comprometia a fazer todas as alterações necessárias no projeto, inclusive, de preservar o meio ambiente e realizar medidas para recuperar as áreas danificadas.

Somente em 30 de novembro de 2009, o empreendedor protocolou nova versão do EIA/RIMA com as adequações solicitadas; encaminhou cópia dos ofícios comprobatórios do encaminhamento destes às Prefeituras das Áreas de Influência Direta e Indireta, bem como às Instituições Estaduais e Federais pertinentes e informou a disponibilidade para realização de Audiência Pública no dia 15 de janeiro de 2010. (SILVA, 2015, p. 8).

\footnotetext{
${ }^{8}$ Primeira denominação do empreendimento.
} 


\section{REGULAÇÃO DO TERRITÓRIO E A GOVERNANÇA LOCAL}

O tema da regulação do território foi inserido no debate sobre desenvolvimento a partir de autores clássicos da literatura internacional, como trata Dallabrida (2010) Segundo esse autor, Lipietz defende que as relações sociais sempre necessitam de regulação uma vez que são contraditórias, passíveis de crise, somando-se ao fato de que as condutas dos atores sociais não se coadunam com as estruturas às quais pertencem.

Ainda segundo Dallabrida (2010) os mecanismos de regulação definem os comportamentos dos agentes a fim de garantir a dinâmica do regime de acumulação, que seriam partes de um modelo de desenvolvimento. O Estado garante a moeda, a relação salarial, a concorrência, a inserção internacional e o modelo de Estado. Em virtude disso, o debate sobre a regulação territorial vincula-se às decisões e ao comportamento dos clusters industriais. Estes efetuam ações nos territórios voltadas à promoção do desenvolvimento local e regional.

Segundo Lins (2006), no estudo da regulação local, são utilizados termos como governança, para indicar o conjunto de atores sociais e de arranjos institucionais presentes em um território, assim como as regras que coordenam tanto as relações internas a este como as estabelecidas com outros territórios. (DALLABRIDA, 2010, p. 167)

Nesse sentido, os arranjos de governança local se constituem um instrumento de mediações, da perspectiva da arena pública. Conforme analisa Ivo (2001, p. 1), o termo governança local "é uma noção genérica utilizada na década de 1990 pelas agências internacionais para o "desenvolvimento", [...] inspiradas na ideia de eficiência do processo de descentralização e eficácia dos governos locais na Inglaterra".

No contexto em análise, o sistema de local governance constitui-se mecanismo de intermediação dos interesses entre Estado, mercado e sociedade civil,

[...] com vistas a criar um Estado eficiente que contemple a construção do desenvolvimento auto-sustentável, através de estímulo à inovação, participação social e descentralização das políticas. Tem, portanto, um sentido de regulação social com vistas à governabilidade e aproxima-se da perspectiva [neoliberal] normativa de "bom governo", no sentido de postular a geração de best practices através da inovação, participação, eficácia; sustentabilidade e confiança, como condições para evitar práticas predatórias nos governos: clientelismo, familismo amoral, corrupção, etc. (IVO, 2001, p. 1).

Os processos de governança envolvem, portanto, formas de interlocução do Estado com os grupos organizados da sociedade, no que se refere ao processo de definição, acompanhamento e 
implantação de políticas públicas, mas atendem à natureza do contexto político. Portanto, na sua dimensão político-institucional são mediações que favorecem o estabelecimento de acordos e "consensos relativos" (IVO, 1997) entre os atores implicados em decisões no âmbito microssocial.

Assim, o conceito incorpora formas de articulação e cooperação entre atores sociais e políticos, arranjos institucionais que coordenem e regulem transações dentro e através das fronteiras do sistema político e, ainda, os mecanismos tradicionais de união de interesses, como partidos políticos e grupos de pressão, passando por redes sociais e associações de diferentes tipos (HOLLINGSWORTH; ROGERS; STREECK, 1993).

No entanto, como analisa Anete Ivo (2001 e 2016), ela não é uma noção neutra, mas os seus resultados resultam das condições de forças entre mercado, sociedade e Estado e têm função de natureza política, dependendo do contexto especifico e da natureza dos agentes. Por meio da governança busca-se aumentar a capacidade de processar as demandas da sociedade e de articulálas com os processos públicos e privados de tomada de decisão. Busca-se um equilíbrio dinâmico entre a eficiência dos mecanismos burocráticos de gestão e a participação dos setores da sociedade civil interessados na sustentabilidade do desenvolvimento. Os entes do Estado, em última instância, prestam conta dos seus atos e da sua eficiência ante as sociedades nacionais (MOURA; BEZERRA, 2016).

As estruturas atuais de governança do setor ambiental para compatibilizarem a natureza interescalar e transetorial dos problemas ambientais supõem uma coordenação horizontal (entre ministérios ou setores) e vertical (entre níveis) de políticas, sendo necessários arranjos colaborativos de um conjunto de atores diversificados e interconectados (LENSCHOW, 2002).

Anete Ivo adverte, no entanto, para o caráter polissêmico e político inscrito nos usos dessa noção, considerando contextos neoliberais, autoritários ou democráticos nos quais a relação entre sociedade, Estado e mercado operam, atendendo prioritária e respectivamente a hegemonia do mercado ou a maior força da sociedade civil em processos de efetivação de controle e participação cidadã, que podem envolver reversão dos fluxos de poder, pela organização e poder social da cidadania organizada. (IVO, 2001; 2016) ${ }^{9}$

O tema da regulação do território abrange várias áreas das ciências humanas e transpõe a relação entre geografia e o direito. Sua abordagem requer a articulação de duas importantes categorias: a técnica e a norma, a partir das quais se pode discutira regulação de uma perspectiva multidisciplinar que a envolve.

${ }^{9}$ Ver especialmente Ivo (2001, p. 61-65; 2016, p. 73-74). 
Antas Jr. (2003) considera a norma uma institucionalização de costumes que passa a reger a vida dos indivíduos. Por um lado, temos as normas morais que influenciam na conviç̧ão interna dos indivíduos e, por outro, as normas jurídicas, externas, impostas pelo Estado, que consistem num conjunto de regras e regulamentações que se tornam cada vez mais complexas à medida em que a sociedade também vai se tornando mais complexa.

Esta articulação implica responsabilidade, direitos e também sanções impostas pelo Estado, caso sejam descumpridas, como no caso das fronteiras e limites entre propriedades e países. Além destas, existem ainda as normas sociais que correspondem à regulação do comportamento no âmbito do convívio social e da cultura, estes sistemas normativos influenciam a configuração socioespacial e o comportamento da sociedade por eles envolvida (ANTAS JR, 2003).

O desenvolvimento nacional, da perspectiva do Estado e da economia, resulta de uma intervenção racional que interfere sobre as relações criativas do homem com a natureza, seja ela espontânea ou criada, atribuindo-lhe materialidades e sendo gerador de ações e novas convenções. Antas Júnior (2003) ressalta a necessidade de tornar visível a intimidade entre forma jurídica e forma geográfica, como propôs Milton Santos.

A norma e a técnica servem para regular o comportamento social, econômico e todas as dinâmicas que se desenvolvem sobre o território, influenciando, assim, a organização e hierarquização das relações neste território.

O conjunto das normas promove, impõe a desigualdade social, dependendo do sistema normativo de que se trata, fortalecendo e ampliando, desse modo, a solidariedade orgânica que, conforme apontou Durkheim, cimenta a divisão do trabalho social. A emergência das técnicas que propiciam a simultaneidade tem trazido normas jurídicas exógenas e rígidas que impõem, aos vários lugares onde a ordem global se instala, a solidariedade organizacional fundada na informação fria e insensível, organizando territórios conforme os objetivos das corporações e instituições internacionais. (ANTAS JR, 2003, p. 3).

Antas Júnior (2003) também observa a maneira como o Estado regula o território. A regulação territorial e social só é exercida por aqueles que detêm o poder de fato e não somente o poder declarado, o que dividiria a regulação entre os poderes imperativos da sociedade: o do Estado, representado na figura dos países ou nações, e o poder da hegemonia corporativa, representado pelo setor econômico. O contrapeso desses poderes na regulação seriam as organizações sociais estruturadas em nível local, regional e/ou nacional, que negociam ou disputam as mudanças do território com o poder econômico, muitas vezes de capital multinacional. 
Milton Santos (2006) alerta para o fato de o Estado atuar como uma espécie de "contabilidade nacional" não autônoma para regulamentar a ação das corporações, por ele chamadas de "contabilidade global" sobre o território, defendendo, disfarçadamente o direito deste.

[...] essa contabilidade nacional é, no fundo, um nome fantasia para a contabilidade global que escolhe, entre as categorias utilizadas, aquelas que privilegiam os interesses de um certo tipo de agente, e excluem todas as categorias de outra índole. E essa contabilidade global se funda em parâmetros inspirados nas próprias finanças globais, num mundo no qual não é mais o capital como um todo que rege os territórios, mas uma parte dele, isto é, o dinheiro em estado puro. Antes o território continha o dinheiro, que era em parte regulado pelo dinheiro, pelo território usado. Hoje, sob a influência do dinheiro, o conteúdo do território escapa a toda regulação interna, trazendo aos agentes um sentimento de instabilidade, essa produção sistemática de medo, que é um dos produtos da globalização perversa dentro da qual vivemos, esse medo que paralisa, esse medo que convoca a apoiar aquilo em que não cremos apenas pelo receio de perder ainda mais (SANTOS, 2006, p.19).

Assim, existe uma ação sinérgica nas corporações entre fomentar o desenvolvimento territorial, exercer o controle sobre sua regulação para depois lucrar com as transformações executadas. Tudo isso limita muito a ação das coletividades locais nas decisões sobre o território.

Sob o ponto de vista da teoria do Direito é pertinente resgatar algumas considerações propostas por Vanzella (2006) sobre a questionável coerência da expressão "teoria da regulação", pois haveria ordenamento jurídico que não seja regulador? O direito por si só já constitui um ordenamento normativo do comportamento humano, pois consiste em um sistema de normas que regulam comportamentos humanos e embora nem toda regulação seja jurídica, tudo o que se caracteriza como direito tem efeito regulador (VANZELLA, 2006).

O autor considera o mercado como uma estrutura institucional sobre a qual o Estado age na sua implantação e manutenção. Sendo o mercado uma estrutura institucional, este é regido pelo Direito, ou seja, possui um conjunto de normas jurídicas criadas para sua regulação, porém ele interfere na própria criação dessas normas, o que o autor caracteriza como "terceiro-ordenador" e "terceiro-árbitro".

O Estado funciona mais como protetor do que como regulador de tal estrutura institucional. E sobre o direito que institucionaliza o mercado, Vanzella afirma (referindo-se a E. Grau) que, 
O direito posto - institucionaliza o mercado. Isso porque as relações de intercâmbio que se desenvolvem no mercado demandam a presença do Estado, ainda que em grau mínimo, como elaborador de normas jurídicas que tutelem a propriedade privada, a autonomia contratual e a heterocomposição de interesses. Razão pela qual um "mercado livre" (ausência do Estado) não corresponde a nenhuma experiência histórica, senão a um modelo ideal. Suas postulações políticas não passam de um engodo: é em virtude do "capitalismo de compadres" (crony capitalism), de que fala P. Arantes, permitindo que a casta financista se confunda com o próprio Estado, que pleiteia o esfacelamento deste último como terceiroordenador e como terceiro-árbitro. (VANZELLA, 2006, p. 818).

O direito privado teria tido sua origem no século XIX, respaldando-se no século XX. Através dele consagraram-se os valores da propriedade privada e da autonomia contratual. Vanzella (2006) cita a configuração do direito público como mero apêndice do direito privado, sendo acionado somente quando o direito privado não é suficiente para resolver os conflitos sociais, como, por exemplo, quando a polícia atua no sentido de garantir liberdades e direitos plurais.

Essa intervenção complementar do Estado a fim de garantir os direitos privados, teria levado o Estado a um processo de perda da confiabilidade da sociedade, com posterior redução significativa das suas ações e a sua substituição como instrumento regulatório por outros destes instrumentos de natureza contraditória, como a autonomia contratual e a propriedade privada (VANZELLA, 2006).

Da experiência de inserção da propriedade privada como alternativa para a regulação surgem experiências mais difíceis no direito, no âmbito da regulação ambiental, uma vez que os elementos naturais que deveriam ser protegidos pelo direito ambiental passam a configurar como propriedade privada por intermédio dos imóveis. Além disso, o autor fala "que os próprios bens ambientais devem ser, em si mesmos, atribuídos a uma pessoa, pública ou privada, para lograr os fins da atividade regulatória" (VANZELLA, 2006, p. 821).

A regulação ambiental, sendo uma área jurídica que se situa entre o direito público e o direito privado, ela

[...] pode ser definida como o conjunto de normas jurídicas protetivas dos bens ambientais (ar puro, água, fertilidade e consistência dos solos, fauna e flora, biodiversidade, ecossistemas), independentemente de tais normas contemplarem formas típicas do Direito Público, tais como determinação e controle de padrões e objetivos e outras imposições e proibições administrativas (exercício do poder de polícia), ou do Direito Privado, tais como responsabilidade, contratos e - o que mais interessa neste estudo propriedade (VANZELLA, 2006, p. 822). 
A regulação ambiental tem interesses primariamente antagônicos aos da regulação econômica, mas apesar disso, visa regular conflitos entre elas (ou seja, entre o ambiental e o econômico) e agir de maneira convergente, ou seja, pela criação de consensos. Ao defender o direito ambiental, cria-se um direito subjetivo da vítima (pessoa alcançada pela lesão ou impacto ao meio ambiente), para o qual se pune o poluidor e, muitas vezes, a pena deste se reverte em direito de crédito para a vítima, o que, dicotomicamente, pode-se classificar também como direito de propriedade.

A regulação ambiental responde sempre com a atribuição de um direito de propriedade: o direito subjetivo ao recebimento da multa, geralmente por parte do Estado, ou o direito subjetivo ao recebimento da indenização, ambos direitos de crédito a ser satisfeito pelo poluidor. Veja-se que previamente a esses direitos de crédito já há a atribuição de um outro direito de propriedade (VANZELLA, 2006, p. 823).

Enquanto a regulação ambiental age de modo distributivo de recursos, a regulação econômica tenta distribuir os custos da preservação ambiental de modo a que o mesmo não seja ônus apenas do agente poluidor (VANZELLA, 2006).

A Constituição Federal (CF) brasileira de 1988 avançou no sentido da regulação ambiental quando concebeu o desenvolvimento não somente como crescimento econômico, mas também sustentável. Segundo o seu artigo 225, o desenvolvimento sustentável é objetivo fundamental de todas as ações do Estado e a regulação econômica deve caminhar junto com a regulação ambiental. Existem duas linhas de proteção ambiental que podem ser utilizadas: uma regula o acesso aos recursos e a outra transforma os recursos em propriedade privada, através de processos de privatização. Nesse sentido, há um potencial conflito de direitos no campo ambiental.

No Brasil, o processo de proteção ambiental baseia-se no direito de propriedade, sendo este necessariamente atribuído à pessoa, física ou jurídica e, a essa pessoa atribuído o direito subjetivo de propriedade privada, submetido ao direito de regime privado. Para tanto, segundo o art. 1.228: "O direito de propriedade deve ser exercido em consonância com as suas finalidades econômicas e sociais", ainda levando em consideração a preservação de recursos naturais (VANZELLA, 2006). O autor fala, ainda, da propriedade pública, quando da função na atividade regulatória.

Ainda no campo da regulação ambiental, é possível que não haja uma atribuição direta de propriedade pública, mas a intervenção estatal nos bens ambientais acaba por transferir, de fato, direitos de propriedade para o Estado. Trata-se de uma propriedade pública implícita, a qual tem lugar a fim 
de transferir ao Estado poderes suficientes para atingir as finalidades regulatórias. Geralmente, a regulação ambiental estabelece modelos mistos de propriedade, os quais compreendem tanto direitos de propriedade privada quanto direitos de propriedade pública sobre bens ambientais (VANZELLA, 2006, p. 829).

A conclusão de Vanzella (2006) é que o melhor tipo de propriedade para se proteger os bens ambientais, sem que seja necessário excluir o ser humano, é a propriedade privada "comum", cujo modelo não existe no ordenamento jurídico brasileiro. A propriedade pública que poderia se configurar num tipo de propriedade adequada para a proteção ambiental apresenta problemas na sua efetividade. Para o autor a "propriedade privada comum" tem como benefícios, impedir materialmente o acesso livre, e a presença de uma pluralidade de sujeitos ao passo que o próprio tipo de propriedade regularia as atividades que exploram o uso ambiental.

Assim, como alternativa sustentável e eficiente de regulação, operaria uma revisão na legislação no que concerne ao direito de propriedade, o que só seria possível a partir de muita organização de atores locais e regionais, pois este tipo de propriedade contraria a lógica do capitalismo vigente.

\section{O ESTUDO DE IMPACTOS AMBIENTAIS (EIA) E O RELATÓRIO DE IMPACTO AMBIENTAL (RIMA): A EFETIVAÇÃO DO PRINCÍPIO DE PREVENÇÃO}

A Resolução 01/86 do Conselho Nacional do Meio Ambiente (CONAMA), órgão responsável por fiscalizar os empreendimentos que podem causar impactos ambientais, estabelece a dimensão socioambiental do risco e diretrizes gerais para o uso e implantação da Avaliação de Impacto Ambiental (estudo de Impacto ambiental e Relatório de Impacto Ambiental - EIA/RIMA), exigido para as atividades consideradas de significativo impacto ambiental.

O documento define impacto ambiental como

[...] qualquer alteração das propriedades físicas, químicas e biológicas do meio ambiente, causada por qualquer forma de matéria ou energia resultante das atividades humanas que, direta ou indiretamente, afetam: a saúde, a segurança e o bem-estar da população; as atividades sociais e econômicas; a biota; as condições estéticas e sanitárias do meio ambiente; a qualidade dos recursos ambientais. (CONAMA, 1986). 
Essa Resolução define o marco normativo e a importância dos estudos de impactos como parte do processo de licenciamento de empreendimentos avaliando o impacto ou a repercussão sobre o meio ambiente e sobre as atividades humanas, permitindo os agentes efetivarem o "princípio de prevenção" que deve presidir decisões de mudança drástica ambiental. Após o governo do Estado da Bahia ser responsabilizado pelo MP e MPF pelo empreendimento, a implementação do projeto passou a ser conduzido pela Superintendência de Desenvolvimento Industrial e Comercial - SUDIC, que contratou a empresa para realização do Estudo de Impacto Ambiental e o Relatório de Impacto Ambiental (EIA/RIMA), a Biomonitoramento e Meio Ambiente Ltda. - BMA. (CNPJ 42.397.505/0001-81, Registro no Cadastro Técnico Federal junto ao IBAMA no $201664)^{10}$.

Do ponto de vista normativo, o estudo representa um instrumento do "Princípio da Prevenção" (controle e prevenção do meio ambiente), na regulação dos territórios, resultante das possíveis mudanças provocadas pelos empreendimentos no território. Analiticamente ele se constituem prognósticos das empresas sobre os riscos ambientais, econômicos, sociais e locais consequentes com o empreendimento, e envolve, portanto, responsabilidades dos empreendedores e dos órgãos públicos quanto à prevenção dos possíveis riscos, com medidas mitigadoras de forma a minimizar, evitar e controlar os riscos identificados.

A sua concepção se orienta pelo princípio da reparação ou minimização do impacto via ações compensatórias, o que supõe indiretamente uma atitude favorável ao empreendimento, e o seu resultado efetiva consensos, atribuindo legitimidade e legalidade ao empreendimento.

Esta parte apresenta dos documentos técnicos - o Estudo de Impacto Ambiental (EIA) e o Relatório de Impacto Ambiental (RIMA) -, exigidos como condição prévia de licenciamento do empreendimento, com base na Constituição da República Federativa do Brasil (1988), CRFB, art. $225, \S 1$, IV, que assegura efetividade do direito ao meio ambiente ecologicamente equilibrado, visando analisar e avaliar os impactos ambientais causados por determinados empreendimentos instalados em áreas que possuem fauna e flora, além de ambientes com Mata Atlântica, demonstrando as possíveis medidas mitigadoras correspondentes.

\footnotetext{
${ }^{10}$ No curso de sua elaboração (EIA/RIMA, 2009), foi realizada nova audiência pública, em 2010. Sendo objeto de análise, a segunda audiência pública, juntamente com os estudos e relatos apontados no EIA/RIMA (2009), além das vistorias técnicas de profissionais do IBAMA, seus resultados foram descritos no Parecer Técnico no 042/2010 - COTRA/CGTMO/DILIC/IBAMA, posteriormente analisado nesta pesquisa.
} 


\begin{abstract}
Ao formular uma prospecção sobre riscos, o diagnóstico traz subjacente uma perspectiva analítica e conceitual assentada nas vantagens comparativas do desenvolvimento econômico produtivo em larga escala e seus efeitos sobre o desenvolvimento local, o que nem sempre é pacífico, e conflita com diferentes setores públicos, em escala regional e nacional. Esse trabalho de prospecção envolve também distintas estruturas conceituais e normativas entre desenvolvimento sustentável e desenvolvimento econômico (área da RESEX X Polo Naval) e valores e formas distintas de percepção da relação homem/natureza e sua compatibilidade com a lógica das atividades produtivas sobre os bens naturais e públicos.
\end{abstract}

Os setores e agentes públicos envolvidos na implantação do projeto do Estaleiro do Paraguaçu eram: o governo do estado da Bahia, representado pelo então governador; a Secretaria Extraordinária da Indústria Naval e Portuária; a Superintendência de Desenvolvimento Industrial e Comercial - SUDIC, sendo responsável diretamente pelo empreendimento a Secretaria de Indústria Comércio e Mineração.

Em 2008, iniciaram-se os estudos locacionais para a implantação de três empreendimentos navais - como inicialmente proposto - os quais estariam localizados, respectivamente: nas proximidades da Baía de Aratu, Madre de Deus e o Baixo Paraguaçu, como locais possíveis para acolher uma instalação deste porte. Posteriormente, em julho do mesmo ano, em razão da profundidade da baía foi decidido que a da construção do estaleiro seria localizada no Baixo Paraguaçu, em Maragojipe, com previsão de construção do empreendimento em três áreas ao longo do Rio Paraguaçu, a saber: Ponta do Corujão, Ponta do Buri e Ponta do Seguro. (SILVA, 2015).

\title{
O CONTEÚDO DO EIA E DO RIMA VINCULADO AO ESTALEIRO
}

Em relação à RESEX o documento esclarece que não há intervenções diretas nessa área, e que essas intervenções ou efeitos aconteceriam somente na Área Diretamente Afetada e na Área de Influência Direta, entretanto, a RESEX está incluída nesta área.

Esta parte do EIA identifica, caracteriza e valora os impactos ambientais causados pela atividade realizada no Estaleiro. Utilizando-se dos dados contidos nos itens anteriores, a avaliação contempla cada etapa do processo, identificando os impactos ambientais mais significativos, que devem ser objeto de programas específicos de controle, mitigação ou ações compensatórias e monitoramento. Deste modo, o documento traça orientações e diretrizes para a adoção de medidas de gestão ambiental do empreendimento. 
$\mathrm{Na}$ avaliação das ações do empreendimento, o documento leva em consideração sua possível interferência com fatores ambientais existentes na sua respectiva área de influência e conclui que é possível verificar, na fase de planejamento, que as únicas interferências esperadas se referem à geração de expectativas da população quanto à instalação do empreendimento.

Nas suas conclusões o estudo aponta 75 impactos, sendo 53 considerados negativos e 22 positivos. O estudo avalia esses impactos por graus de significância e conclui que $45 \%$ dos resultados são de Alta Significância, 39\% de Baixa Significância e 16\% de Média Significância. O texto também sistematiza a distribuição dos impactos pelo caráter positivo e negativo, por meio avaliado, além de fazer uma comparação entre os positivos e os negativos.

Com base na análise dos dados, o estudo conclui, nessa parte, que os benefícios positivos decorrentes da implantação do Estaleiro do Paraguaçu superariam os possíveis impactos negativos, desde que todas as medidas mitigadoras e programas identificados ao longo da avaliação de impactos fossem implementados junto ao projeto.

Sob o ponto de vista da reestruturação regional e dos possíveis efeitos sociais do empreendimento, o EIA estima que a implantação do Estaleiro do Paraguaçu pode direcionar a região para duas situações opostas:

a) se esta implantação for bem elaborada tomando todos os cuidados possíveis em relação aos fatores ambientais, culturais e econômicos, seria possível colher resultados positivos, no que diz respeito à melhoria das condições de vida das comunidades e à manutenção das atividades tradicionais (inclusive a pesca) com suas características e valores culturais.

No entanto, caso a implantação de uma indústria naval deste porte ocorra em espaços físicos utilizados tradicionalmente para atividades de pesca artesanal, e seja feita de forma "atropelada", sem a participação dos atores locais, esta intervenção poderá expor as comunidades pesqueiras a um processo de desagregação social, associado ao colapso dos recursos naturais, gerando um passivo ambiental e social de difícil remediação.

O EIA efetuou a análise da situação ambiental do local onde o empreendimento seria implantado, identificando as possíveis alterações que poderiam ocorrer, tanto na fase de obras ou de implantação quanto na fase de operação do empreendimento, avaliando os impactos positivos e negativos sobre o meio ambiente local. 0 resumo desse estudo consolida-se no Relatório de Impacto Ambiental - RIMA, que deve ter uma linguagem de acesso mais fácil para o entendimento e discussão pela população. Ele contém os dados mais relevantes para a análise ambiental da área e os dados sobre os impactos ambientais previstos na área. 
Esse relatório sintetiza as etapas de implantação do empreendimento em dois momentos: a primeira, de implantação ou de construção, na qual estariam previstas atividades como remoção da vegetação, terraplenagem, implantação das fundações, vias de acesso, obras de drenagem, redes elétricas, hidráulicas e outras; e, a segunda fase, a de operação, quando o estaleiro já estaria construindo as embarcações. Esta fase envolveria a compra e estocagem de materiais e as fases mecânicas e de acabamento das embarcações. Para a primeira fase previa-se a criação de 3.900 empregos diretos para construção, com nível mínimo educacional exigido de ensino médio completo. Para a fase de operação, previa-se a criação de 4.000 postos de emprego de diversos níveis de escolaridade, contradizendo a estimativa do próprio Governo do estado da Bahia, que anunciou a criação de $20 \mathrm{mil}^{11}$ empregos diretos e indiretos com a implantação do empreendimento.

Acompanhando as conclusões do EIA, o RIMA indica também dois cenários possíveis pósimplantação do empreendimento: o primeiro considera que todos os cuidados devidos teriam sido tomados. Nesse caso os resultados da implantação do empreendimento seriam positivos e a atividade pesqueira mantida, promovendo desenvolvimento local; o segundo cenário considera que se os processos e cuidados apontados não fossem cumpridos, ocorreria prejuízo da atividade pesqueira, degradação ambiental e socioeconômica.

O conteúdo das prospecções indicadas nos documentos EIA/RIMA, a reestruturação e a regulação territorial seguem três ciclos processuais de convenções públicas e regras institucionais, em relação ao território local:

a) a definição da região como reserva extrativista, no âmbito da legislação nacional de preservação do meio ambiente, de 2000 , que respeita e considera as populações pesqueiras, extrativistas integradas à dinâmica da reserva;

b) as estratégicas de implantação e localização do estaleiro, que implicou decisões institucionais sobre o território em favor da realização da dinâmica e do projeto econômico;

c) a paralisação do empreendimento, como resultado da crise institucional e política brasileira, que redefine relações e arranjos anteriores entre a esfera pública e privada.

\footnotetext{
${ }^{11}$ Novo Polo Industrial Naval no Recôncavo vai gerar 20 Mil Empregos. Disponível em http://www.secom.ba.gov.br/2013/11/70673/novo-polo-industrial-naval-no-reconcavo-vai-gerar-20-milempregos.html.
} 


\section{O PROCESSO DE REPARAÇÃO DOS RISCOS: a mediação dos atores}

Formalmente, o Consórcio cumpriu com a entrega dos documentos necessários para que a licença fosse concedida, considerando, inclusive, as notificações do Ministério Público para levar em conta as demandas da comunidade na Audiência Pública em que os moradores da comunidade participaram.

Ocorre que, em 02 de dezembro de 2009, o IBAMA publicou no Diário Oficial da União o edital no qual informou sobre o recebimento do EIA/RIMA e sobre a realização da Audiência Pública no dia 18/01/2010, que foi realizada no município de Maragojipe. (SILVA, 2015, p. 8).

A 2a Audiência pública com a comunidade, posterior à divulgação do RIMA, teve participação expressiva de 1.313 pessoas, e nela muitos moradores (maioria pescadores) reiteraram sua oposição ao empreendimento no município de Maragojipe. Além de uma síntese do que foi o processo de licenciamento do Estaleiro, o Parecer Técnico (042/2010, p. 25) sistematiza um resumo da audiência. Realizada na sede da Associação Atlética Maragojipana, a audiência teve início às 18:30h, conduzida pelo Coordenador de Mineração e Obras Civis do IBAMA, sendo encerrada às 2 horas da manhã do dia 19 de janeiro. Após a exposição feita pelo empreendedor, foi dada a palavra aos participantes para que formulassem perguntas ou para que fizessem a inscrição para manifestação oral, conforme descrito a seguir:

As intervenções, em $87 \%$ (oitenta e sete por cento) dos casos, versaram sobre os impactos sociais do empreendimento. Destes, cerca de $40 \%$, relacionavam-se a questões de emprego, capacitação da mão de obra e programa de primeiro emprego para os jovens, o que demonstra a grande preocupação da comunidade com essa questão. Algumas perguntas fizeram referência aos impactos sobre a população ocasionados pela grande massa de trabalhadores a se instalar nos locais. Como era de se esperar, cerca de $10 \%$ dos questionamentos referiam-se aos impactos sobre o meio físico e biótico. Houveram muitas manifestações de apoio ao empreendimento e questões sobre o aproveitamento da mão de obra local nas várias fases do empreendimento. Foi detectada, na audiência, uma preocupação com a capacitação da população local para que os mesmos possam acessar um dos benefícios mais importantes para a população que é o emprego. Além disso, foram feitas referências ao acompanhamento das medidas compensatórias e mitigadoras. Os $3 \%$ restantes se referem a manifestações não afetas aos impactos do empreendimento. (PARECER TÉCNICO № 042/2010, p. 24).

Observa-se que a comunidade local apresenta relativa percepção das dificuldades e impactos que enfrentaria com a implantação do Estaleiro, tendo maior prevalência os problemas no meio socioeconômico, evidenciando-se os impactos resultantes da chegada de populações 
oriundas de outras regiões, e que se expressam em dificuldades dos jovens serem contratados pelo Estaleiro, dada as limitações de oferta de capacitação da mão de obra, além das dificuldades de oferta educacional à população jovem que chega ao município, em decorrência da pouca infraestrutura educacional local para o seu acolhimento adequado.

Em menor grau, apenas 10\% dos participantes perceberam que o empreendimento é uma oportunidade de formalização do emprego, e manifestaram apoio à implantação do Estaleiro. Além dessas preocupações, ocorreram também ponderações sobre os impactos no meio físico e biótico.

Em que pesem essas críticas, formuladas antes mesmo do início das obras do Estaleiro, os esforços das autoridades públicas e privadas em favor do empreendimento foram exitosos e, em 2010, o Instituto Brasileiro do Meio Ambiente e dos Recursos Naturais Renováveis-IBAMA, principal órgão federal de fiscalização ambiental, liberou a licença para que o empreendimento fosse implantado. (SILVA, 2014).

Um dos grupos residentes na área onde o Estaleiro seria instalado compunha-se das famílias quilombolas, juridicamente registradas no Instituto Nacional de Colonização e Reforma Agrária (INCRA), pelo Decreto no 4.887, de 2003, órgão responsável pelo registro de Quilombos ${ }^{12}$, e que tinham, portanto, direitos garantidos quanto aos seus territórios e as suas culturas. Reconhecendo o direito dessa comunidade ao território, o Ministério Público Estadual recomendou ao IBAMA, que o valor da multa que o Consórcio responsável pelo Estaleiro deveria pagar fosse usado prioritariamente para reparar esses impactos e ajudar as famílias quilombolas da Reserva.

A legislação ${ }^{13}$ prevê que o consórcio responsável pelo empreendimento além de pagar multa pela área que seria afetada, também promova iniciativas e atividades que recuperassem parte da área degradada, e que as famílias que vivem da pesca, impactadas pelo Estaleiro fossem também ressarcidas, considerando que o seu trabalho foi prejudicado com a construção das obras do empreendimento. Como explicam os trechos da recomendação do Ministério Público Federal ao IBAMA.

CONSIDERANDO que a instalação de empreendimentos ou atividades efetiva ou potencialmente capazes de causar significativo impacto ambiental negativo, deflagra a obrigatoriedade da incidência do instituto da Compensação Ambiental estabelecido pelo artigo 36 da Lei 9.985/00,

\footnotetext{
${ }^{12}$ As comunidades quilombolas são grupos étnicos - predominantemente constituídos pela população negra rural ou urbana -, que se autodefinem a partir das relações específicas com a terra, o parentesco, o território, a ancestralidade, as tradições e práticas culturais próprias. (INCRA, 2017).

${ }^{13}$ Constituição Federal, que no seu art. 225, caput, dispõe sobre o reconhecimento do direito a um meio ambiente sadio como uma extensão ao direito à vida, seja pelo aspecto da própria existência física e saúde dos seres humanos, seja quanto à dignidade desta existência, medida pela qualidade de vida. Este reconhecimento impõe ao Poder Público e à coletividade a responsabilidade pela proteção ambiental.
} 
mediante a técnica da compensação pecuniária reversível para fins ambientais. (SILVA, 2015, p. 8).

A recomendação do Ministério Público Federal estabeleceu medidas financeiras compensatórias às famílias afetadas, reconhecendo que suas vidas sofreram uma mudança drástica no seu modo de subsistência, a exemplo das atividades da pesca e mariscagem na região, que ficaram comprometidas com o violento impacto das obras no ambiente marinho. Nesse sentido, o valor da multa aplicado ao Estaleiro deveria ser utilizado em caráter de urgência pelas famílias quilombolas atingidas.

Embora o Plano Diretor de Desenvolvimento Municipal - PDDM $^{14}$, de 2010, vinculado ao interesse local de recepcionar os ganhos econômicos do Estaleiro, aponte para a existência de 200 famílias com um total de 1.000 habitantes, o EIA-RIMA, apresentou um quantitativo de famílias no local de cerca de 400 afetadas diretamente pelo empreendimento. Essas, em sua maioria, viviam da pesca e mariscagem por estarem situadas à margem do rio Paraguaçu. Além dessa atividade foi registrado também o artesanato como fonte de renda da comunidade. (SILVA, 2015).

Todas as decisões e decretos realizados sempre foram favoráveis ao empreendimento, incluindo a diminuição da área da RESEX, pela Medida Provisória 462/2009, mesmo com a possibilidade de causar danos e prejuízos às famílias extrativistas e riscos ao meio ambiente, como foram evidenciados até o momento. Uma entrevista realizada com liderança local comprova posição favorável da população ao empreendimento, como pode-se ler a seguir:

[...] a comunidade tanto de São Roque, quanto a Enseada, sempre foram adepto pela execução da obra [estaleiro], sempre foram de acordo com a instalação do estaleiro aqui. Eles aceitaram e aprovaram a questão da vinda do estaleiro, a manutenção [...]. Nesse período de instalação houve realmente esse compromisso [participação da comunidade], inclusive até eu participei das audiências públicas que teve aqui em São Roque, na Enseada, teve também audiência em Maragojipe, teve entrevista com pescadores, com moradores, houve participação [...]. Na minha concepção, a vinda do estaleiro para aqui até que foi uma coisa boa, porque nós somos uma comunidade tradicional, ou seja, pescadores, trabalhadores rurais, nós temos esse histórico, mas temos que entender que em todo lugar o desenvolvimento tem que surgir, como, por exemplo, em Icapanema o comércio era forte, mas quando o comércio de saveiros cheios de mercadoria para Salvador quebrou, Icapanema voltou a ser uma tapera, um local morto. Então eu vejo o seguinte: se na minha comunidade as coisa não houver desenvolvimento, não chegar empresas, não chegar indústrias, também a

\footnotetext{
${ }^{14} \mathrm{~A}$ escolha pela utilização dos dados oriundos do PDDM é dada para compreender de que modo o município quantifica tais famílias, concluindo que por estarem mais próximo da população local, através das secretarias de Saúde e de Ação Social, os números se revelam mais próximos da realidade local.
} 
gente fica parado no tempo. A gente sabe que o progresso tem que acontecer, agora que venha com responsabilidade. Eu não vi como uma coisa ruim não, porque houve uma melhora de vida para as pessoas, então desde quando ele tenha continuidade e tendo um compromisso, responsabilidade social e com o meio ambiente eu não vejo nada de errado. (Entrevista Com João Cerqueira da Costa, representante da comunidade, membro do conselho da RESEX, realizada em 29/01/2019).

A região da Baía de Iguape, local de implantação do empreendimento, tem um relevante histórico de preservação, entre as baías que se localizam no interior da Baía de Todos os Santos. Com a implantação do Estaleiro Enseada, toda a vida marinha dessa baía corre riscos, por conta da incidência dos ruídos e barulhos proporcionados pela preparação da área, montagem dos equipamentos, e a alteração ambiental resultante de cada etapa anterior. Mesmo com a realização dos estudos (EIA e RIMA) apontando para grandes prejuízos à vida marinha, o IBAMA liberou a licença prévia no 354/2010 para o empreendimento. (MARTINS, 2010).

Muito embora desde o início o IBAMA tenha explicitado com firmeza seriedade na avaliação "objetiva" do impacto, parece que pressões políticas ou do tempo político resultaram na aprovação final do empreendimento, como se pode deduzir de relatos coletados na entrevista:

Foi uma discussão muito desgastante [2a audiência pública] com populares a favor, outros contra, havia membros da academia, muitas pessoas do movimento ambientalista. Mas o que tudo indica é que o pessoal do IBAMA não aprovou o empreendimento, só que eles foram convidados, chamados a Brasília, tiveram uma conversa e eles terminaram sob pressão liberando o empreendimento. Ouvi dizer também... Não tenho certeza que uma das representantes do IBAMA chegou a pedir transferência. (Entrevista com Francisco José Ferreira Souto, professor e membro da Comissão Pró-Iguape, realizada em 17/12/2018).

O processo de compatibilidade entre desenvolvimento econômico afinado com a preservação do meio ambiente tem sido reconhecido em todo o mundo, a exemplo das Conferências Rio+10 (2002), e a Rio+20, (2012), nas quais, foram pactuados compromissos globais dos Estados com a preservação das metas de preservação do desenvolvimento sustentável com a presença de vários líderes mundiais. 


\section{OS PRINCIPAIS ATORES RESPONSÁVEIS PELA IMPLANTAÇÃO DO ESTALEIRO}

Na sequência destacam-se os principais atores que atuaram na tomada de decisão do empreendimento: o governo estadual e a instância da justiça (pelo Ministério Público).

\section{O governo estadual: um ator decisivo na implementação do projeto}

O governo estadual mobilizou inúmeros recursos e processos para que as decisões relativas ao empreendimento seguissem um curso ágil e favorável à instalação do Estaleiro. O executivo estadual buscou convencer a sociedade local sobre a importância desse empreendimento para a localidade, e orientou decisões favoráveis à política nacional e estadual de implementação econômica de investimentos, como destaca Martins (2010).

Sabia-se, no entanto, que a área escolhida apresentava uma vida marinha muito sensível, e que no momento em que as obras iniciassem, essa vida marinha estaria comprometida. (CARVALHO; HEIMER, 2015).

O empreendimento Estaleiro Enseada resulta da necessidade estratégica de grandes embarcações no país, e se volta para permitir maior expansão econômica no Recôncavo Baiano. (IBAMA, 2010). A empresa Sete Brasil surgiu em 2010 para construir as sondas que iriam explorar as áreas de pré-sal no Brasil. (G1, 2017). Os estudos prévios realizados (EIA-RIMA) para a instalação do Estaleiro previam que os materiais necessários para a construção do empreendimento chegariam pelo mar, e as estradas já existentes e as que seriam construídas pelo governo do estado da Bahia, também seriam vias de transportes para esses materiais. (IBAMA, 2010).

Esses elementos associados ao processo de implantação do empreendimento permitem avaliar a extensão do impacto territorial e socioeconômico da região e sinalizam para a necessidade de serem garantidos os direitos da população de moradores locais e as ações compensatórias.

Considerando as recomendações dos estudos e as ações posteriores observa-se que as prospeç̧ões feitas em relação ao projeto não foram cumpridas e o Parecer Técnico no 042/2010 foi também desrespeitado: as embarcações que transitavam pelas imediações, fazendo a logística da construção do empreendimento, continuaram suas atividades sem qualquer interferência. As estradas foram completamente degradadas, continuando, assim, até a reforma da BA 534, que liga parte do trecho à via de acesso à Enseada do Paraguaçu. Com investimento de "R\$25,14 milhões, o governador do Estado só entregou 27,8 quilômetros da rodovia BA-534 recuperada, em Salinas 
da Margarida, no dia 15 de outubro de 2016, trecho do entroncamento da BA-001, em Conceição de Salinas, até Cairu - Enseada"15.

Os resíduos gerados durante a implantação do empreendimento também deveriam ter destinação prevista, antes mesmo da iniciação das obras. O parecer exigia a instalação de um aterro sanitário que pudesse atender à demanda da obra na região, já que na localidade não tinha estrutura suficiente, o que não foi também atendido. (IBAMA, 2010). Esse debate acerca da destinação dos resíduos gerados pelo empreendimento é fundamental porque, além do modo como a implantação ocorreu ter devastado uma grande área de Mata Atlântica, a obra gerou muito entulho, lixo de obra que precisa ser acomodado em algum lugar, o que, não tendo sido feito de forma adequada, gerou a degradação do meio ambiente.

Da análise do parecer técnico (042/2010) conclui-se que o estudo das obras de implantação do empreendimento apresenta falhas, erros e falta de dados que comprometem a determinação da sua viabilidade ou não, resultando na impossibilidade de atestar, portanto, a viabilidade ambiental dada a ausência ou inconsistência de informações fundamentais para o posicionamento técnico.

Um argumento decisivo levantado pelo governo do estado da Bahia sobre a importância do empreendimento foi, principalmente, o da geração de empregos. Previa-se, na primeira etapa da obra a criação de 3.600 empregos, e, depois de sua instalação, a contratação de 4.000 funcionários, com prioridade para a população local. Assim, o Serviço Nacional de Aprendizagem Industrial (SENAI) firmou convênio com o consórcio para oferecer os profissionais capacitados. (IBAMA, 2010).

A geração de empregos, mesmo de natureza temporária, ligados à construção do empreendimento, e a dinamização da economia local pelo aumento de demandasse constituíram em duas pautas relevantes e justificadoras do empreendimento como propulsor de um desenvolvimento socioeconômico do território, mas os impactos gerados implicaram o mesmo grau de preocupação sobre o protagonismo governamental.

Todo o processo de implantação do empreendimento confrontou os anseios e expectativas dos moradores locais com os interesses governamentais de implantação do projeto para dinamizar a economia. De acordo com a avaliação atual de um dos moradores locais, foram realizadas algumas

\footnotetext{
${ }^{15}$ Disponível em: http://www.infraestrutura.ba.gov.br/2016/10/10118/Estrada-BA-534-e-recupera-eentregue-em-Salinas-da-Margarida.html. Acesso em: 27 nov. 2016.
} 
melhorias por parte do governo que dinamizaram a economia, mesmo reconhecendo que efetivamente houve danos importantes no ambiente marinho.

Há aproximadamente 40 anos quase, que São Roque se tornou distrito, aqui foi construído o canteiro da Petrobras, aqui em São Roque. Aí houve umas paradas na área naval, no nosso país. Com a chegada do estaleiro houve uma expectativa muito grande da comunidade em gerar emprego, em gerar renda, das coisas se desenvolverem aqui na comunidade. E que na realidade, quando o estaleiro chegou e que começou a suas atividades, São Roque começou realmente a se desenvolver. É que dependeu muito do poder público para que as coisas fossem mais é... com ênfase maior. A chegada foi de grande expectativa e de grande importância para a gente aqui. São Roque estava parada na realidade, e com a chegada do estaleiro tinha até algumas obras anteriores dentro do próprio canteiro da Petrobras: de plataformas, teve também alguns consórcios anteriores ao estaleiro. Mas o estaleiro, ele veio como algo que iria mudar, transformar São Roque e transformar a Enseada. Então, foram muitos investimentos, foram pousadas, restaurantes, as pessoas começaram a criar seus próprios negócios, o dinheiro começou a se movimentar e as pessoas começaram a ter uma condição de vida melhor. Isso foi de grande importância. Muitas pessoas começaram a ter cursos profissionalizantes, muitas pessoas tiveram, se prepararam e hoje essas pessoas estão trabalhando fora daqui, com esses cursos que foram feitos aqui na comunidade oferecidos pela empresa. O impacto teve, como eu disse. Mas o pessoal soube lidar, na esperança de melhorar a vida quando o estaleiro funcionasse. (Entrevista com João Cerqueira da Costa, representante da comunidade, membro do conselho da RESEX, realizada em 29/01/2019).

Como afirmam Carvalho e Heimer (2015, p. 2), numa avaliação geral o governo atuou politicamente para efetivar o empreendimento de modo que a sua instalação se concretizasse, viabilizando decretos, medidas provisórias e leis, por um lado, e exercendo papel de articulador político entre os agentes, de forma a permitir a sua implantação. No âmbito das arenas de debate uma estratégia adotada foi a neutralização das discussões sobre o tema, como apontam esses autores.

Essa percepção entre o prometido, o estudado e o comprometido pode ser identificado na entrevista realizada com representante da Comissão Pró-Iguape. Para ele esse processo de implantação do estaleiro foi feito de forma totalmente de cima para baixo, não houve participação, embora tenha havido algumas audiências públicas. Na verdade, nada para as comunidades opinarem. Existia um projeto do governo federal e do governo estadual com apoio do governo municipal, em articulações com as empreiteiras para implantação do projeto. E foi feito sem efetivo diálogo com as comunidades, com a própria RESEX ou o ICMBio. Existiram de fato audiências 
públicas, mas não eram processos consultivos. Seguiam um roteiro, trâmites burocráticos, porque as coisas de fato já estavam decididas.

O autor da presente tese teve a oportunidade de participar de uma audiência pública com a apresentação de alguns resultados que foram bastante questionados: [...] eles se defenderam de fato. Mas é uma discussão meio que proforma, a impressão que dava é que as coisas estavam totalmente decidias e estavam só apresentando. Era sempre uma questão de tramite burocrático. Não existiam uma... Eles respondiam as perguntas os questionamentos, eu fiz alguns inclusive; muito furado, vários furos, mas não foi uma coisa amplamente discutida não. A tensão se baseou nos resultado que foram desmentidos, de certa forma, pela comissão. A tensão foi um pouco esta. Na verdade, eles dizem que a conclusão do EIA/RIMA é que não tem impactos fortes e a gente de certa forma combatia isso. A tensão foi muito em função dessas discussões. Eles falavam uma coisa, se defendiam, mas coisas que não eram defensáveis. Mas era a palavra deles contra a nossa. Mas, como referido, não foi algo deliberativo; eles simplesmente apresentavam o previamente decidido. A audiência pública foi, por assim dizer, um negócio bizarro. Algumas lideranças já haviam sido cooptadas pelo empreendimento, na verdade o empreendimento pagou, financiou um monte de ônibus para que esses populares fossem, porque eram favoráveis à instalação do empreendimento. Não saberia dizer ao certo a quantidade de pessoas, mas com certeza umas 200 pessoas, mediadas pelo secretário especial de porto, mas estava na mesa também o pessoal do IBAMA, representante da prefeitura. Tinha representante de todas as comunidades da RESEX. Uma coisa bem dividida. Muita gente cooptada. Fizeram a cabeça dizendo que ia ter emprego pra todo mundo, então foi uma briga ferrenha, muito desgastante. Teve início às $19 \mathrm{~h}$ a referida audiência, um horário impróprio para os pescadores se deslocarem; foi de propósito isso, meio que armado, e foi uma discussão muito pesada. Mas volte-se a chamar a atenção, não era um espaço em que ia se decidir nada. As coisas já estavam decididas. Era só um trâmite legal para ser cumprido. Foi uma discussão muito desgastante, com populares a favor, outros contra, havia membros da academia, muitas pessoas do movimento ambientalista. (Entrevista com Francisco José Ferreira Souto, professor e membro da Comissão Pró-Iguape, em 17/12/2018).

A partir da percepção apontada pelo representante da Comissão, pode-se concluir que o papel do governo, em suas diferentes escalas, mas, sobretudo, o governo federal, foi central no processo de aceitação da comunidade, inclusive na mobilização dos atores, no formato dos eventos e na cooptação através do discurso desenvolvimentista.

\section{O Ministério Público: mediador da justiça ambiental redistributiva}

O empreendimento trouxe muitas mudanças ao município de Maragojipe, desde o início de suas obras, em 2010. Do ponto de vista positivo, os empregos gerados direta e indiretamente 
alavancaram a economia, o município aumentou sua arrecadação de impostos, converteu esta arrecadação em estruturação de serviços, como a construção e melhorias na saúde e educação, atestado pela entrevista realizada, assim como a obra trouxe grande visibilidade ao município.

Mas o meio ambiente sofreu grande degradação, desde a paisagem, como se pode verificar comparativamente por fotografias de antes e depois, que revelam uma destruição impressionante do ambiente: a vida marinha foi alterada, com prejuízo e sofrimento das famílias que dependiam da pesca e da mariscagem. As fotografias abaixo mostram o impacto físico socioambiental da área, resultante das obras de instalação do empreendimento.

A Figura 01 mostra o distrito de São Roque antes do Estaleiro e a Figura 02 mostra o Canteiro de Obras após o inicio da implantação do Estaleiro.

Figura 01 - Distrito de São Roque antes do Estaleiro

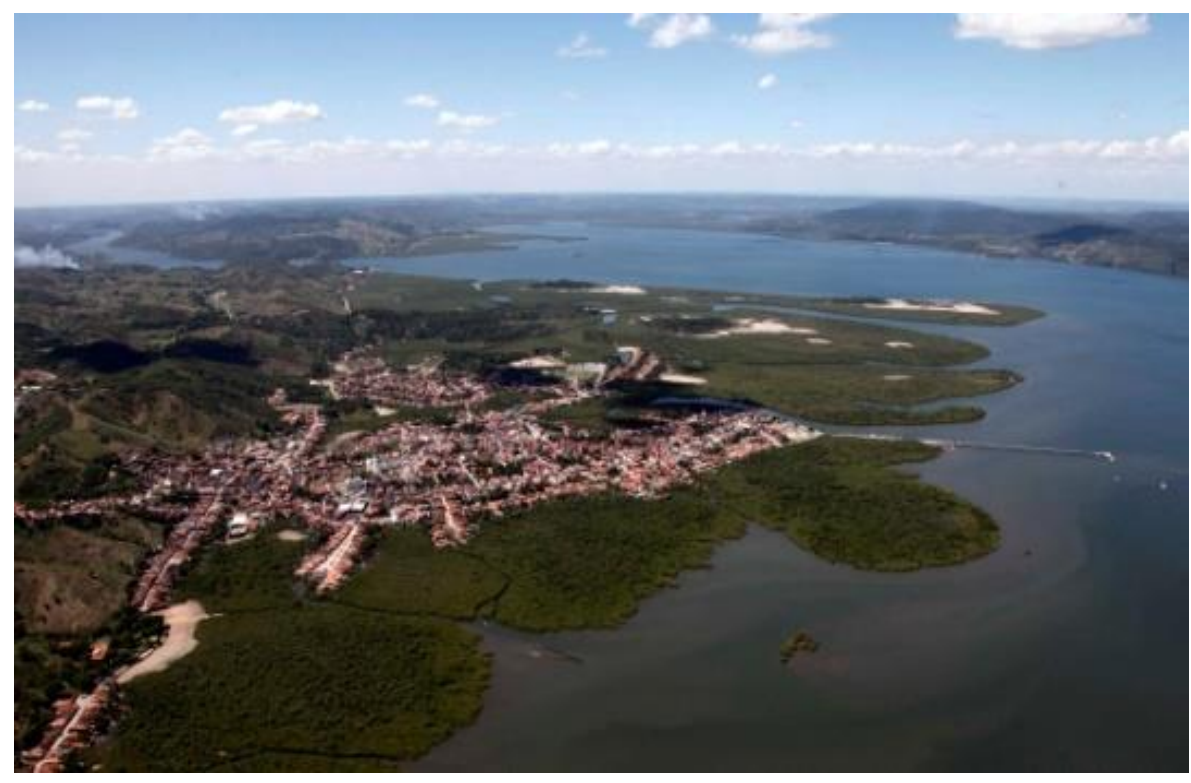

Fonte: Silva (2014). 
Figura 02 - Canteiro de Obras após o inicio da implantação do Estaleiro

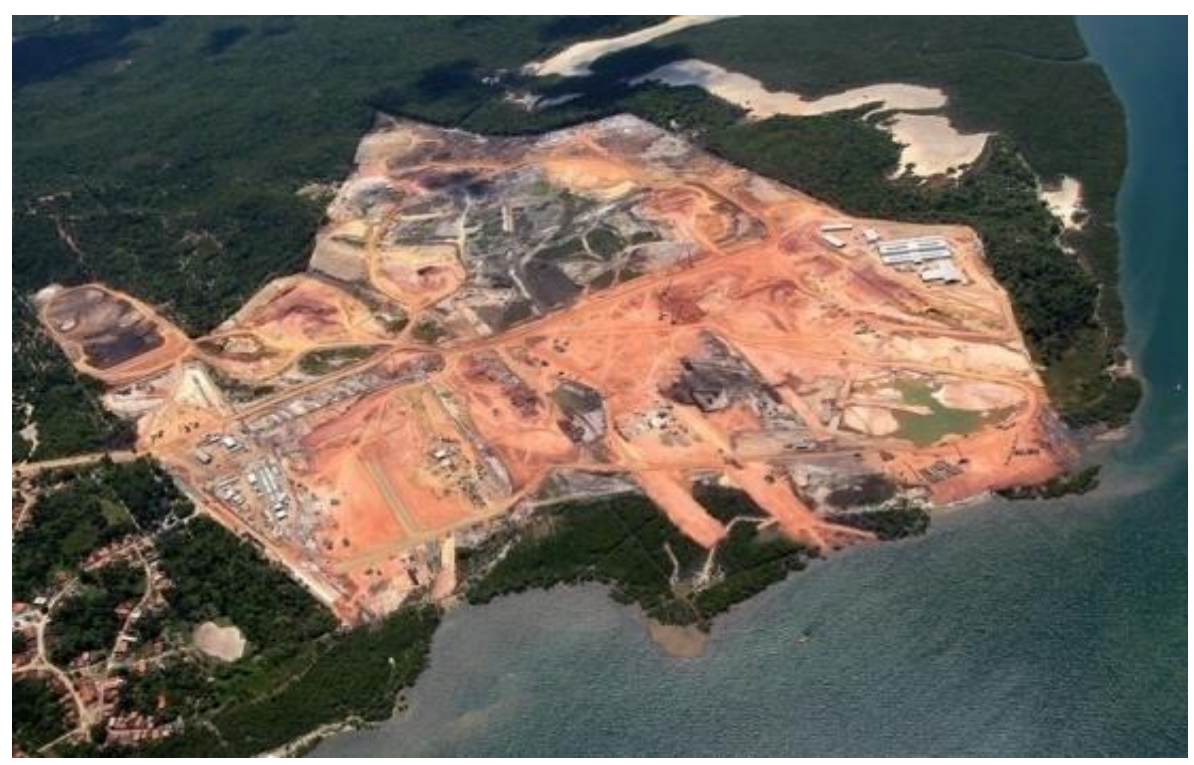

Fonte: Silva (2014).

Os impactos dessas alterações foram determinantes para que o Ministério Público Estadual interviesse, recomendando ao IBAMA que a multa paga pelo empreendimento fosse utilizada para ressarcir as famílias que tiveram sua atividade de renda prejudicada, e, só depois que as famílias fossem indenizadas, o dinheiro deveria ser utilizado para solucionar alguns problemas ambientais da região. (SILVA, 2015). Isso porque o Ministério Público entendeu que a lei declara que quando uma empresa, empreendimento ou pessoa agride o meio ambiente, deve ocorrer uma compensação, uma indenização paga, destinada a essa reparação.

A recomendação foi encaminhada ao IBAMA, justamente por ser o órgão responsável por estabelecer as multas, de acordo com o grau do dano causado ao meio ambiente, cabendo ao órgão administrar o valor para que as compensações fossem realizadas de forma imparcial e responsável. Como as famílias da localidade foram afetadas, deveriam ter seus prejuízos ressarcidos, podendo assim cobrir seus prejuízos durante um tempo razoável, estipulado pelo órgão.

Conforme o próprio Estudo de Impacto Ambiental já explicitava, a implantação do empreendimento implicou um conjunto de impactos, a saber:

Essa área sofrerá intervenções diretas das atividades inerentes ao empreendimento, tais como a supressão de vegetação, terraplanagem, implantação de linhas de energia e sistema de abastecimento de água, canteiro de obras, construção de cais de acostagem, dique seco, rampas, área administrativas, área industrial, áreas de utilidades, dentre outras, além da área destinada a Reserva Legal. (EIA, 2009, p. 13) 
Trata-se, portanto, do anúncio prévio da supressão de vegetação nativa, aterramento da área do manguezal, da dragagem do estuário para aprofundamento do calado de atracação, e da emissão de efluentes líquidos (basicamente esgoto), resíduos sólidos decorrentes do desmatamento.

O IBAMA, por gozar de autonomia administrativa, pode decidir como distribuir e qual a prioridade a ser dada com o valor da multa indenizatória. Neste propósito o MP expediu recomendação ao órgão para utilizar o recurso de forma imparcial e a que todos os que foram prejudicados com a instalação do Estaleiro pudessem seguir suas vidas, sem maiores prejuízos.

A região de implantação do Estaleiro, a Baía de todos os Santos (BTS), possui uma significativa população formada por comunidades tradicionais que subsistem dos recursos naturais da região. Portanto, qualquer impacto nesse meio ambiente e nesses recursos, reflete-se sobre as condições de reprodução dessas populações. Nesse sentido, os impactos ambientais no local são indissociavelmente articulados comas dimensões socioeconômicas.

Os impactos prospectados pelo EIA/RIMA e o cronograma da instalação do estaleiro não foram efetivados e o impacto das obras trouxe implicações negativas e prejuízos além das previstas para a região, alguns dos quais são relatadas a seguir.

Os danos causados à organização sociocultural das famílias, que realizavam atividades transmitidas por gerações de pais para filhos, são evidentes. Os danos a esse segmento foram irreversíveis, daí por que a intervenção do MP se constituiu uma importante mediação jurídica, tanto para essas famílias, mas, também, na defesa do meio ambiente.

Os argumentos que fundamentaram a decisão indenizatória do Ministério Público chamam a atenção para a importância da área da reserva extrativista e do direito das famílias quilombolas:

CONSIDERANDO que, para os pescadores artesanais das comunidades da Baía do Iguape, a RESEX se tornou um importante instrumento jurídico no combate à pesca predatória com o uso de explosivos e uma estratégia política para atrair a atenção do Governo Federal para a região; 
CONSIDERANDO que a partir de 2005, 18 dentre as 23 comunidades rurais de pescadores/lavradores do entorno da RESEX (aproximadamente 2000 famílias) se auto identificaram como quilombolas. (SILVA, 2015).

Essas considerações do MP foram decisivas na defesa dos interesses dessa comunidade afetada, e se constituiu uma vitória para os que militam em defesa do meio ambiente e que, no caso específico, haviam se colocado contrários à implantação do Estaleiro pelos riscos não quantificáveis do empreendimento. Por essa decisão os danos às famílias e ao meio ambiente foram destacados como relevantes, de forma a que o valor da multa fosse aplicado de forma imparcial, produzindo uma justiça compensatória.

\section{ENTRE A PROSPECÇÃO DOS ESTUDOS E O ESPAÇO FÍSICO RECONFIGURADO}

O primeiro impacto da implantação das obras ocorre em termos de alteração física do território e, de acordo com Carvalho e Heimer (2015), implicou a supressão de 150 hectares de vegetação nativa da Mata Atlântica e de manguezais, após alteração da poligonal da RESEX Baía do Iguape, o que trouxe, por consequência, alterações da fauna e flora locais e uma imensurável alteração na distribuição das espécies.

Como exemplo deste processo, a Figura 03 permite visualizar a extensão estrutural envolvida no processo do Estaleiro, bem como parte do espaço de terra devastada, exibindo a escala das transformações socioeconômicas sobre o território do empreendimento.

Figura 03 - Canteiro de Obras do Estaleiro (20 de novembro de 2013)

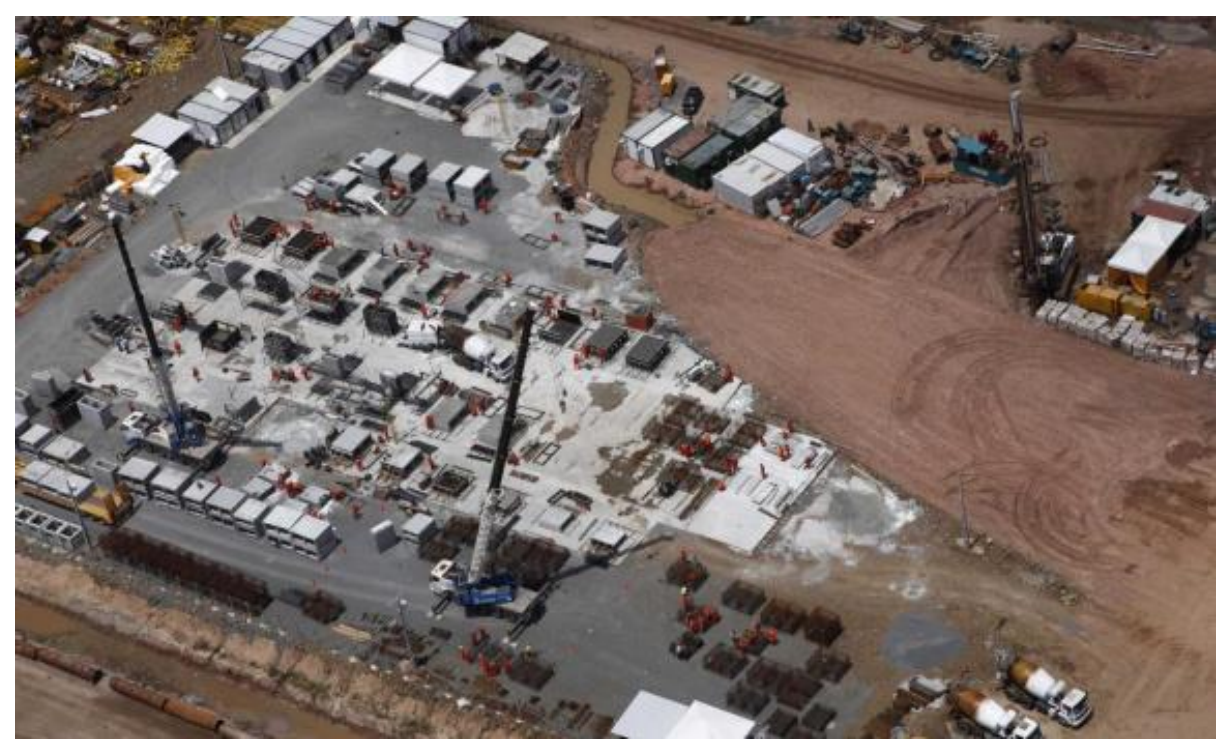

Fonte: Silva (2014, p. 79). 
Após o início das obras constatou-se que a alteração da profundidade da Baía do Iguape, necessária para a passagem de embarcações e as plataformas do estaleiro, implicou a paralisação das atividades da pesca e mariscagem por seis meses. Para minimizar esse dano, que desestruturou a ordem socioeconômica e cultural pré-existente e o meio de vida de parte das populações locais, o consórcio responsável pelo empreendimento realizou um cadastro, por iniciativa do Ministério Público, para indenizar os pescadores. O processo de cadastramento, no entanto, colocava em dúvida a habilitação de vários cadastrados, além de não reconhecer o prejuízo material das marisqueiras.

Conforme analisam Carvalho e Heimer (2015) e Soares et al. (2009), a BTS já sinalizava uma diminuição expressiva de pescados em 2002, 2005 e 2006, conforme Figura 04, e após a implantação das obras foi verificado o desaparecimento de várias espécies de peixes, crustáceos e mariscos, como bagre, tainha, xangó, entre outros, além de mariscos, entre eles o siris. Uma espécie de algas jamais encontrada na região passou a se proliferar, causando o apodrecimento das redes de pesca (CARVALHO; HEIMER, 2015), evidência constante do parecer técnico elaborado pela Comissão Pró-Iguapé, que interferia nas atividades econômicas da comunidade pesqueira e marisqueira.

Figura 04 - Médias e Desvios Padrão da Produção extrativista marinha de pescados dos municípios da Baía de Todos os Santos, BA - 2002, 2005 e 2006.

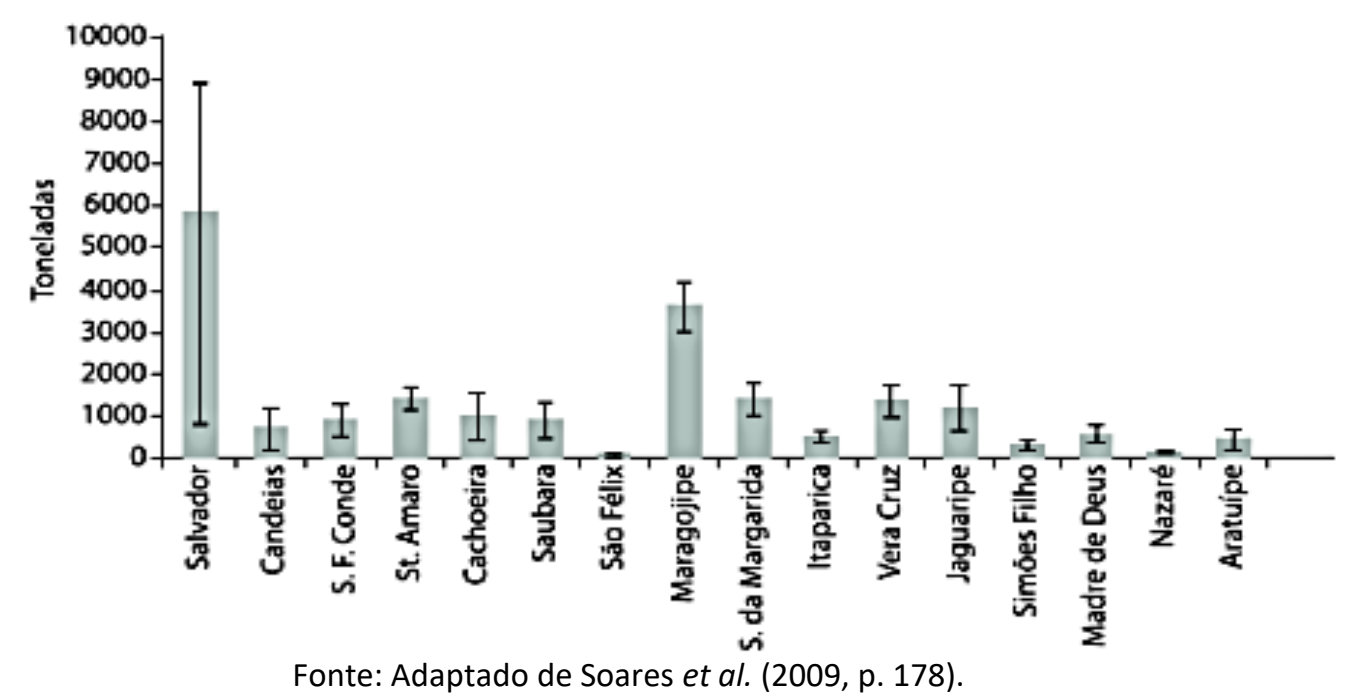

Outro impacto relevante identificado por esses autores em função da sobreposição do empreendimento em área da Comunidade Remanescente de Quilombo de São Francisco do Paraguaçu, localizada em Cachoeira, resultou em transferência de competência de desapropriação 
da área, antes realizada pelo INCRA para o ICMBio. Essa mudança implicou deslocamento de responsabilidade pública no acompanhamento do empreendimento sobre o território, uma vez que a concessão das comunidades tradicionais no interior da RESEX torna-se propriedade da União, facilita que fazendeiros pleiteiem terrenos dentro desta área e que populações quilombolas que não pratiquem atividades extrativistas percam o direito sobre elas.

Silva (2015) já denotava a preocupação com o fato de o empreendimento ter sido proposto numa Área de Influência Direta onde vivem 18 comunidades pesqueiras e 13 comunidades remanescentes de quilombos, a exemplo da comunidade Quilombo Enseada do Paraguaçu, objeto do seu estudo.

Uma vez rede limitada a poligonal (BRASIL, 2009), outras restrições foram impostas aos quilombolas, afetando a organização de vida e trabalho dessa população, como a proibição de criar animais de grande porte. Por outro lado, o novo quadro de regulação institucional impõe exigências de permissão do ICMBio para construções ou ampliação de edificações na área. "O ministro do Meio Ambiente havia se comprometido (com a preservação do modo de vida das comunidades tradicionais) na ocasião da modificação dos limites da RESEX, o que não foi devidamente cumprido, e estas restrições impactaram diretamente sobre a vida cotidiana dessas comunidades" (CARVALHO, HEIMER, 2015).

A RESEX, como especificado no capítulo do EIA, é uma unidade de conservação cujo objetivo de proteção inclui as populações locais as quais, junto ao órgão ambiental, o ICMBio, cogerenciam o território onde estas vivem, participando da gestão e contribuindo com o conhecimento ambiental tradicional. Essas áreas são registradas como propriedade real de uso coletivo. Mesmo assim, têm sido cenário de disputas fundiárias e de outros interesses econômicos, conforme analisa Prost (2010) em estudo sobre a RESEX Baía do Iguape, que antecipou a instalação do empreendimento do estaleiro.

Nesse estudo Prost identificou um total de 20.000 pessoas, divididas em 20 comunidades, vivendo essencialmente da pesca artesanal, tanto no consumo direto quanto na comercialização dos pescados. Ela destaca o caráter contraditório do agente público, o Estado, que deveria cumprir o papel de proteção ambiental e das populações tradicionais e que, ao invés disso, abre concessões econômicas e legais que interferem na dinâmica e na sobrevivência dessas populações. 
Como colocado na parte dedicada à zona costeira, para ordenar a ocupação e o uso do espaço é preciso que um agente público, o Estado, intervenha de modo a prevenir ou resolver conflitos. Na área de estudo, no intuito de proteger o ambiente natural e cultural da Baía do Iguape, uma RESEX marinha criada por decreto, em 2000. A criação expressa o reconhecimento do valor ecológico da área, mas também o das populações tradicionais e, enquanto tal, portadoras do direito de fixar sua territorialidade. (PROST, 2010, p. 58).

A RESEX Baía do Iguape resultou de iniciativas de um grupo de pescadores que solicitou ao Instituto do Meio Ambiente - IBAMA, a criação desta RESEX. Portanto, bem antes da constituição do projeto do Estaleiro. Apenas em 2005, foi criado o Conselho Deliberativo da RESEX Baía do Iguape, com caráter deliberativo cuja composição garantia maior representatividade dos agentes vinculados à atividades extrativistas, com um percentual de $50 \%$ sendo que os outros $50 \%$ se distribuíam entre representantes de órgãos públicos e demais instituições do setor privado e do terceiro setor, atuantes na área da RESEX. Essa composição na cogestão do Conselho Deliberativo garantia maior controle dos grupos associados às atividades extrativistas sobre as decisões da área da RESEX.

A iniciativa do governo em implantar o Estaleiro desconsiderou toda essa dinâmica social política e institucional anterior e não estabeleceu qualquer diálogo com as comunidades locais e o Conselho Deliberativo da RESEX, dando início ao plano de intervenção local de forma autoritária já que desconsiderou, nas etapas iniciais, a participação das comunidades no processo ${ }^{16}$, principais afetados pelo empreendimento.

Assim, a implantação do projeto do estaleiro pela forma como definido e implementado opôs desde o início, duas concepções de desenvolvimento: aquele do qual o PAC se constituía o principal modelo de intervenção, atendendo aos interesses nacionais; e o outro, que considerava a dinâmica socioambiental das populações pré-existentes como elemento decisivo de desenvolvimento social local.

Impactos negativos foram percebidos não apenas por pescadores e marisqueiras, mas também pela comunidade quilombola do território Salamina Putumuju, que sofreu intervenções da instalação do estaleiro após a Empresa Paraguaçu Engenharia requerer e ganhar, sob ação

\footnotetext{
${ }^{16}$ Prost (2010), sobre a Unidade de Conservação e as competências do Conselho Deliberativo: Assim que aprovado o plano de uso, toda pessoa pertencente a uma RESEX ou não, deve respeitar as regras de uso dos recursos naturais no perímetro da referida UC a fim de preservar os recursos naturais e a vida do grupo social que delem subsistem. O Conselho Deliberativo tem como função o controle social sobre os acontecimentos em curso ou projetados, dentro da RESEX ou na área do seu entorno $(10 \mathrm{~km})$. Qualquer ação sobre o meio natural ou o território deve ser previamente submetida ao Conselho.
} 
judicial, a suspensão dos efeitos legais de interesse social do referido território quilombola, atrapalhando o processo de regularização fundiária da comunidade ${ }^{17}$. Cabe salientar que

A especulação imobiliária decorrente da implantação de um empreendimento desse porte e seus efeitos sobre as terras ocupadas por comunidades tradicionais que não possuem a titularidade de suas áreas não foi contabilizada como possível impacto negativo no EIA/RIMA, mesmo que o referido estudo tenha identificado a existência de vários grupos quilombolas em processo de regularização fundiária nas áreas de influência direta e indireta do estaleiro. Em virtude disso, nenhuma ação ou programa de titulação dos territórios quilombolas da região foi previsto como ação compensatória ou mitigatória (CARVALHO; HEIMER, 2015, p. 18).

A não-identificação de impacto sobre os quilombolas significa no fundo uma forma de "não - reconhecimento" desse segmento como sujeito de direitos, em relação ao projeto e aos compromissos mitigadores das ações compensatórias a serem implementadas. Carvalho e Heimer (2015) constatam falhas na elaboração de estudo antropológico sobre os impactos nessas comunidades, uma vez que não foram emitidas condicionantes, explicitando essa necessidade aos órgãos licenciadores. Entre as dificuldades causadas aos povos quilombolas da região pela implantação do empreendimento pode-se citar, de acordo com relatos dos que vivem a realidade, a dificuldade de acesso aos locais tradicionais de pesca e mariscagem, que passou a ser realizado somente por via fluvial; o aumento dos conflitos e tensões entre os trabalhadores do consórcio e os moradores locais, evidenciado pelas manifestações de desacordo entre eles.

No âmbito da dinâmica econômica local, elemento motivador principal para o consentimento da comunidade local ao empreendimento, observou-se uma grave crise com demissões e a falência dos pequenos negócios abertos quando da expansão das obras, o que gerou muita insatisfação e desestabilização econômica. Segundo Carvalho e Heimer (2015), muitos destes negócios foram abertos com as economias das famílias ou empréstimos feitos por elas.

Neste sentido, o que se observa é que, mesmo após o anúncio e com as obras de construção em finalização em 2010, os territórios ocupados pelas comunidades tradicionais da Baía de Todos os Santos (BTS) mantiveram o mesmo padrão de indicadores socioeconômicos em relação ao padrão geral do país. É o que revelam os indicadores do Índice de Desenvolvimento Humano Municipal - IDHM e de renda per capita de seis principais municípios - Cachoeira, Itaparica,

\footnotetext{
${ }^{17}$ Ainda em Carvalho e Heimer (2015): a empresa Paraguaçu Engenharia em ação ordinária 41.72864.2011.4.01.3300, obteve a antecipação dos efeitos de tutela para suspensão parcial dos efeitos do decreto presidencial de interesse social do território quilombola de Salamina Putumuju, referente ao imóvel Fazenda Mutuca.
} 
Maragojipe, Salinas da Margarida, São Félix e Saubara - comparados aos indicadores do país, conforme Tabela a seguir:

Tabela 1 - Indicadores de IDHM e Renda Per Capita (EM R\$)

\begin{tabular}{lllllll}
\hline LUGAR & $\begin{array}{l}\text { IDHM } \\
(\mathbf{1 9 9 1 )}\end{array}$ & $\begin{array}{l}\text { IDHM } \\
\mathbf{( 2 0 0 0 )}\end{array}$ & $\begin{array}{c}\text { IDHM } \\
\mathbf{( 2 0 1 0 )}\end{array}$ & $\begin{array}{c}\text { RENDA } \\
\mathbf{( 1 9 9 1 )}\end{array}$ & $\begin{array}{c}\text { RENDA } \\
\mathbf{( 2 0 0 0 )}\end{array}$ & $\begin{array}{c}\text { RENDA } \\
(\mathbf{2 0 1 0})\end{array}$ \\
\hline Brasil & 0,493 & 0,612 & 0,727 & 447,56 & 592,46 & 793,87 \\
\hline Cachoeira & 0,399 & 0,536 & 0,647 & 159,84 & 239,23 & 368,11 \\
\hline São Félix & 0,388 & 0,489 & 0,639 & 161,74 & 223,36 & 299,65 \\
\hline Maragojipe & 0,341 & 0,456 & 0,621 & 117,89 & 170,15 & 300,1 \\
\hline $\begin{array}{l}\text { Salinas da } \\
\text { Margarida }\end{array}$ & 0,373 & 0,466 & 0,617 & 122,67 & 148,32 & 286,45 \\
\hline Saubara & 0,352 & 0,502 & 0,617 & 141,35 & 204,5 & 265,17 \\
\hline Itaparica & 0,407 & 0,522 & 0,670 & 138,52 & 257,05 & 476,99 \\
\hline
\end{tabular}

Fonte: Atlas Brasil (2013).

Da Tabela 1, constata-se que no tocante ao IDHM, os municípios da BTS apresentaram média de 0,376 pontos em 1991; já o Brasil apresentou 0,493 pontos, ultrapassando os municípios em 0,117 pontos. No ano de 2010, os municípios da BTS mostraram média de 0,635 pontos, enquanto o Brasil apresentou 0,727, mantendo 0,092 pontos de diferença no IDHM. Ou seja, no curso de duas décadas os avanços no IDHM da região mantiveram os mesmos níveis assimétricos de disparidades.

No que se refere ao indicador de renda per capita, verifica-se que os municípios da BTS apresentavam, em 1991, uma renda média de $\mathrm{R} \$ 138,66$, enquanto que a renda média para o Brasil era $\mathrm{R} \$ 447,56$. Após duas décadas, a renda per capita média dos municípios da BTS é de $\mathrm{R} \$ 332,74$, enquanto o Brasil apresentou uma renda média per capita de $\mathrm{R} \$ \mathbf{7 9 3 , 8 7}$. Mantém-se, portanto, um mesmo padrão de renda média per capita do período, com evolução da renda per capita regional abaixo dos padrões do país. 


\section{CONSIDERAÇÕES FINAIS}

A análise empreendida por este estudo demonstrou que os danos previstos no Estudo de Impacto Ambiental estavam muito aquém da dinâmica socioambiental localizada e ocorrida no território, presentes no processo de implantação do Estaleiro.

Os argumentos mobilizados pelos proponentes do empreendimento para convencimento e legitimação junto à população local, apresentados na primeira Audiência Pública e o Parecer Técnico no 042/2010 do MPF, não foram capazes de cumprir o princípio da prevenção e protegerem o meio ambiente, nem alcançaram respostas às demandas das comunidades abrigadas nas áreas de implantação, descumprindo e desrespeitando, portanto, as promessas anunciadas e utilizadas em grande medida como estratégia de aprovação do empreendimento. Essa dissociação entre o discurso e a efetividade na prevenção e garantia contra riscos demonstra um processo de seletividade pelo qual se reconvertem acordos em favor dos atores mais fortes, no caso para os fins e objetivos definidos pelas empresas e governos.

Independente da evolução tecnológica e industrial e de como o indivíduo tem evoluído, o meio ambiente precisa ser conservado. Portanto, os órgãos que cuidam do meio ambiente e que fiscalizam seu manejo devem buscar os meios legais que viabilizem o cumprimento da lei de controle ambiental, mesmo que esse objetivo possa frustrar grandes interesses econômicos e políticos em disputa, o que tem configurado um confronto de concepções sobre os caminhos globais do desenvolvimento, entre países.

Observa-se, portanto, que as normativas relativas ao princípio de preservação do meio ambiente ultrapassa os limites nacionais e locais e abrangem formas regulatórias internacionais pactuada entre os países. O global apresenta então princípios regulatórios contraditórios: de um lado, o apoio ao livre mercado, de natureza ultraliberal, permitindo a espoliação de bens naturais, sem qualquer interferência dos estados nacionais. Nesse caso os Estados, sob hegemonia do mercado, passam a funcionar internamente na desregulação do acesso a terra e bens naturais e públicos em favor de corporações econômicas globais. Do outro, os acordos e pactos globais dos ambientalistas comprometem os Estados nacionais e países com ações de preservação e prevenção de atividades compatibilizando o desenvolvimento econômico e a acumulação às regras de garantia do meio ambiente e direito à vida, como princípio universal já que os danos se alastram e repercutem em termos planetários. 
Do ponto de vista constitucional, os dispositivos e princípios que buscam assegurar a preservação do meio ambiente não foram observados. As condicionalidades explicitadas para minimizar os impactos da instalação do estaleiro, desconheceram a variável física - o movimento das marés -, o contingente efetivo de população atingida, e a ordem sociocultural que se desestruturou com a implantação do empreendimento. Tampouco foram seguidas com rigor a fiscalização do cumprimento dessas obrigações. Ademais, as regulações e a dinâmica das atividades políticas e econômicas ultrapassam em muito o funcionamento da atividade no local e, no caso desse projeto, não era possível prever-se uma reversão da política nacional e o processo de destituição política e retração econômica, nem os impedimentos de grandes empresas nacionais consolidadas, participantes do Consórcio. O processo de desregulação das atividades corresponde a um processo de expropriação política do projeto nacional endógeno, pela destituição do grupo no poder, eliminando-o do controle da crise estrutural do capitalismo no âmbito nacional e afastando-o do controle geopolítico dos recursos do petróleo.

Uma das justificativas apresentadas no documento (EIA/RIMA) como impacto positivo do empreendimento era a criação de postos de trabalho para a população local. O RIMA previa a geração de 3.900 empregos diretos para a fase de implantação e 4.000 para a fase de operação. Essa dinâmica foi gravemente comprometida com a interrupção das obras, resultante de grave crise institucional no país, de proporções inesperadas e que atingiu inicialmente a Petrobras e por consequências as empresas participantes do Consórcio para o empreendimento.

De acordo com a documentação consultada e a literatura visitada sobre o empreendimento pode-se concluir que, no processo de elaboração do EIA, não houve uma escuta suficiente das comunidades a respeito das mudanças que seriam impostas às suas rotinas, e dos prejuízos sobre suas atividades da pesca e na mariscagem, contrariando o impacto positivo de "redução da pressão sobre os estoques pesqueiros durante a implantação e a operação" previsto no RIMA. Não foi levado em consideração sequer o período de seis meses sem pesca, e a não-indenização das marisqueiras. Da mesma forma as dificuldades enfrentadas pelo consórcio gestor, de identificação dos trabalhadores a serem indenizados evidenciam a distância entre o prognóstico do empreendimento no plano da retórica e dos documentos públicos e as condições vividas e experimentadas por segmentos da sociedade afetados pela do empreendimento.

A promessa explicitada no RIMA de "aumento da biodiversidade no entorno do cais do empreendimento" tornou-se contrária ao enunciado, transformando-se em alteração das espécies existentes da fauna marinha, com prejuízo da atividade pesqueira e, principalmente, da mariscagem. 
De tal modo, a análise empreendida por este estudo demonstrou que os danos previstos no Estudo de Impacto Ambiental estavam muito aquém da dinâmica socioambiental localizada e ocorrida no território, presentes no processo de implantação do Estaleiro, implantado após consenso e alterações realizadas no processo legislativo-político.

\section{REFERÊNCIAS}

ANTAS JR., R. M. A Norma e a técnica como elementos constitutivos do espaço geográfico: Considerações sobre o ressurgimento do pluralismo jurídico. In: SOUZA, M. A. Território Brasileiro: Usos e Abusos. Campinas: Territorial, 2003. p.77-92.

ATLAS BRASIL 2013. Atlas do Desenvolvimento Humano no Brasil: IDHM de Maragojipe. 2013. Disponível em: http://atlasbrasil.org.br/2013/perfil/Maragojipe_ba. Acesso em: 20 out. 2018. BRASIL. Constituição (1988). Constituição da República Federativa do Brasil. Brasília, DF, Senado, 1998.

Lei $\mathbf{n}$. 12.058, de 13 de outubro de 2009. Dispõe sobre a prestação de apoio financeiro pela União aos entes federados que recebem recursos do Fundo de Participação dos Municípios FPM, no exercício de 2009, com o objetivo de superar dificuldades financeiras emergenciais; altera as Leis $\mathrm{n}$ os 11.786 , de 25 de setembro de 2008, 9.503, de 23 de setembro de 1997, 11.882, de 23 de dezembro de 2008, 10.836, de 9 de janeiro de 2004, 11.314, de 3 de julho de 2006, 11.941 , de 27 de maio de 2009, 10.925, de 23 de julho de 2004, 9.636, de 15 de maio de 1998, 8.036, de 11 de maio de 1990, 8.212, de 24 de julho de 1991, 10.893, de 13 de julho de 2004, 9.454, de 7 de abril de 1997, 11.945, de 4 de junho de 2009, 11.775, de 17 de setembro de 2008, 11.326, de 24 de julho de 2006, 8.427, de 27 de maio de 1992, 8.171, de 17 de janeiro de 1991, 5.917, de 10 de setembro de 1973, 11.977, de 7 de julho de 2009, 11.196, de 21 de novembro de 2005, 9.703, de 17 de novembro de 1998, 10.865, de 30 de abril de 2004, 9.984, de 17 de julho de 2000, e 11.772, de 17 de setembro de 2008, a Medida Provisória no 2.197-43, de 24 de agosto de 2001, e o Decreto-Lei no 1.455, de 7 de abril de 1976; revoga a Lei no 5.969, de 11 de dezembro de 1973, e o art. 13 da Lei no 11.322, de 13 de julho de 2006; e dá outras providências. Disponível em: http://www.planalto.gov.br/ccivil_03/_Ato2007-2010/2009/Lei/L12058.htm. Acesso em: 20 out. 2016.

Medida Provisória n. 462, de 2009. Dispõe sobre a prestação de apoio financeiro pela União aos entes federados que recebem recursos do Fundo de Participação dos Municípios - FPM, no exercício de 2009, com o objetivo de superar dificuldades financeiras emergenciais, e dá outras providências. Disponível em: https://www.congressonacional.leg.br/materias/medidasprovisorias/-/mpv/91076. Acesso em: 20 ago. 2017.

. Ministério do Planejamento. 11 Balanço Completo do PAC - 4 anos (2007 a 2010). 2012. Disponível em: http://www.pac.gov.br/sobre-o-pac/publicacoesnacionais. Acesso em: 27 set. 2017. 
. Ministério do Meio Ambiente. MMA.

Instituto Brasileiro Do Meio Ambiente E Dos Recursos Naturais Renováveis. IBAMA.

PARECER TÉCNICO № 042/2010-COTRA/CGTMO/DILIC/IBAMA.2010. Disponível

em:https://comissaoproiguape.files.wordpress.com/2010/05/parecer-tecnico.pdf. Acesso em: 25 jun. 2017.

. Ministério do Meio Ambiente. MMA. Conselho Nacional do Meio Ambiente. CONAMA.

Resolução no. 001, 23 jan., 1986. Disponível em:

http://www.mma.gov.br/port/conama/res/res86/res0186.html. Acesso em: 25 jun. 2017.

CARVALHO, A. P. C.; HEIMER, M. Análise dos impactos do Estaleiro Enseada do Paraguaçu,

Maragojipe/BA, com o auxílio da Geotecnologia. Anais, IV CONGRESSO LATINO AMERICANO DE

ANTROPOLOGIA DA ASSOCIAÇÃO LATINO AMERICANA DE ANTROPOLOGIA, 2015, Cidade do México. 2015.

DALLABRIDA, V. R. Desenvolvimento e governança territorial: um ensaio preliminar sobre a necessidade de regulação no processo de gestão do desenvolvimento. Redes, Santa Cruz do Sul, v. 15, n. 3, p. 165-186, 2010. Disponível em:

https://online.unisc.br/seer/index.php/redes/article/view/1029/1249. Acesso em: 02 abril 2018.

EIA/RIMA. Estudo de Impacto Ambiental e Relatório de Impacto Ambiental do Estaleiro do

Paraguaçu. SUDIC: Salvador, 2009.

FERREIRA, Í. A. A Escolha Pública Como Determinante da Implantação do Estaleiro Enseada Indústria Naval e Seus Efeitos no Território Local. Revista de Humanidades, Tecnologia e Cultura, Bahia. 2017. Disponível em:

http://www.fatecbauru.edu.br/ojs/index.php/rehutec/article/download/299/212. Acesso em: 15 maio 2018.

G1. Petrobras retomará negociações com a Sete Brasil. Globo. Bahia, 23 de junho 2017. Disponível em: https://g1.globo.com/economia/negocios/noticia/petrobras-retomaranegociacoes-com-a-sete-brasil.ghtml. Acesso em: 19 jul. 2017.

HOLLINGSWORTH, J.; ROGERS, P. S.; STREECK, W. (eds.). Comparing capitalist economies: variations in the governance of sectors. Oxford: Oxford University Press, 1993.

INCRA, Instituto Nacional de Colonização e Reforma Agrária. RTID. 2017. Disponível em:http://pesquisa.In.gov.br/imprensa/jsp/visualiza/index.jsp?data=13/03/2017\&jornal=3\&pagin $\mathrm{a}=1 \&$ totalArquivos=220. Acesso em:17maio 2017.

IVO, Anete B. L. Democracia, Cidadania e Pobreza - A produção de novas solidariedades. (Introdução ao Dossiê) Caderno CRH, v. 10, n. 26/27, p. 9-17,1997.

Governança urbana, participação social e pobreza. Capítulo 3. In: IVO, Anete B. L.

Metarmorfoses da questão democrática: governabilidade e pobreza. Buenos Aires: Consejo Latinoamericano de Ciencias Sociales, 2001. (Colección Becas CLACSO-ASDI). p. 61-82. 
. A noção de governança. Um novo regime de ação para o desenvolvimento sustentável e a produção das ciências sociais. In: Anete B. L. Ivo. (Org.). A reinvenção do desenvolvimento: agências multilaterais e produção sociológica. 01 ed. Salvador: EDUFBA, 2016. p. 37-104.

LENSCHOW, A. "Greening" the European Union: are there lessons to be learned for international environmental policy? Global Environmental Change, v. 12, p. 241-245, 2002. Disponível em: https://onlinelibrary.wiley.com/doi/abs/10.1002/10990976\%28200005/06\%2910\%3A3\%3C109\%3A\%3AAID-EET227\%3E3.0.CO\%3B2-Z Acesso em: 20 maio 2018.

MARTINS, V. Documento de Avaliação do Eia/Rima Estaleiro Paraguaçu. Consultoria para elaboração do Relatório final sobre o Estudo de Impacto Ambiental - EIA e Relatório de Impacto Ambiental - RIMA do Estaleiro do Paraguaçu, Bahia. 2010. Disponível em:http://www.ceama.mpba.mp.br/boletim-informativo/doc_view/2209-consultoria-paraelaboracao-do-relatorio-final-sobre-o-eia-rima-estaleiro-praguacu.html. Acesso em: 31 dez. 2016.

MOURA, A. S.; BEZERRA, M. C.. Governança e sustentabilidade das políticas públicas no Brasil. In: MOURA, A.S (org). Governança Ambiental no Brasil: instituições, atores e políticas públicas. Brasília: IPEA, 2016. Disponível em: http://www.ipea.gov.br/portal/images/stories/PDFs/livros/livros/160719_governanca_ambiental _cap04.pdf

PROST, C. Resex marinha versus polo naval na Baía do Iguape. In: IV SIMPÓSIO INTERNACIONAL DE GEOGRAFIA AGRÁRIA, 2009, Niterói. Anais, V Simpósio Internacional de Geografia Agrária. v. 1. p. 1-17.

Eixo Temático: Pesca Artesanal e Unidades de Conservação. Discursos sobre sustentabilidade e áreas protegidas, 2010. Disponível em: https://repositorio.ufba.br/ri/bitstream/ri/7327/1/Prost_FUNDAJ.2010.pdf. Acesso em: 22 maio 2018.

SANTOS, M. O dinheiro e o território. In: SANTOS, M. [et. al.]. Território, Territórios: Ensaios sobre o ordenamento territorial. 2.ed. Rio de Janeiro: DP\&A, 2006. p. 7-13.

SILVA, Carlos Augusto Oliveira da. O capitalismo e o Recôncavo da Bahia: análise do processo de implantação do Estaleiro Enseada do Paraguaçu. 255 p. Dissertação (Mestrado). Cachoeira: UFRB, 2014. Disponível em: http://cdn.jornalgrandebahia.com.br/2014/12/O-Capitalismo-e-oRec\%C3\%B4ncavo-da-Bahia-\%E2\%80\%93-an\%C3\%A1lise-do-processo-deimplanta\%C3\%A7\%C3\%A3o-do-Estaleiro-Enseada-do-Paragua\%C3\%A7u.pdf. Acesso em: 12 fev. 2017.

SILVA, Sida da. A sobreposição de territórios: a indústria naval no quilombo Enseada do Paraguaçu em Maragogipe/BA. 108 p. Dissertação (Mestrado Profissional). Cachoeira: UFRB, 2015. 
SOARES et al. Pesca e Produção Pesqueira. Baía de Todos os Santos: aspectos oceanográficos. In: HATJE, V. ANDRADE, J (org.). Pesca e Produção Pesqueira. Salvador: EDUFBA, 2009. p. 157-206. VANZELLA, R. D. F. Direito de Propriedade e Regulação Ambiental. Revista da Faculdade de Direito da Universidade de São Paulo, v. 101, p. 815-828, 2006.

Trabalho enviado em 29 de julho de 2019 Aceito em 17 de fevereiro de 2021 